\title{
Energy management on industrial parks in Flanders
}

\section{Tom Maes ${ }^{\mathrm{a}, *}$, Greet Van Eetvelde ${ }^{\mathrm{a}}$, Evelien De Ras ${ }^{\mathrm{a}}$, Chantal Block $^{\mathrm{b}}$, Ann Pisman $^{\mathrm{c}}$, Bjorn Verhofstede ${ }^{\mathrm{c}}$, Frederik Vandendriessche ${ }^{\mathrm{d}}$, Lieven Vandevelde ${ }^{\mathrm{e}}$}

\author{
${ }^{a}$ Ghent University, Faculty of Engineering, Civil Engineering Department, Section Mobility and Spatial Planning, Research Team Environmental and Spatial Management, \\ Vrijdagmarkt 10/301, B-9000 Gent, Belgium \\ ${ }^{\mathrm{b}}$ Leuven Engineering College Groep T, Department of Chemical Engineering, Vesaliusstraat 13, B-3000 Leuven, Belgium \\ ${ }^{\mathrm{c}}$ Ghent University, Faculty of Engineering, Civil Engineering Department, Section Mobility and Spatial Planning, Vrijdagmarkt 10/301, B-9000 Gent, Belgium \\ d Ghent University, Faculty of Law, Public Law Department, Universiteitstraat 4, B-9000 Gent, Belgium \\ e Ghent University, Faculty of Engineering, Department of Electrical Energy, Systems and Automation, Sint-Pietersnieuwstraat 41, B-9000 Gent, Belgium
}

\section{A R T I C L E I N F O}

\section{Article history:}

Received 29 October 2010

Accepted 22 November 2010

\section{Keywords:}

Eco-industrial park

Mixed industrial park

Energy management

Carbon footprint

\begin{abstract}
A B S T R A C T
In the race against climate change, aiming for low-carbon competitiveness, Flanders has initiated a carbon neutrality strategy on industrial parks, building towards energy efficient buildings and processes, acting as a stimulus for the production and consumption of green electricity. However, premises and internal process optimisation on industrial parks is not considered sufficient to limit greenhouse emissions in Flanders. Structural transition is called for, aiming for industrial clustering and energy autonomy based on renewables. Therefore, the concept of industrial symbiosis is analysed to determine how it could improve the energy-related carbon management on industrial parks. This article explores the literature on industrial symbiosis and eco-industrial parks searching for specific energy strategies, and is illustrated with case studies. Energy management on industrial parks can be integrated in the entire development process and park management. Maximising efficiency is a promising local optimisation issue, in which business should be engaged, stimulated and facilitated. By clustering buildings and processes, by energy exchange, collective production and joint contracting of energy services, local synergies can be intensified. Yet, uncertainty and variability in time of energy consumption can keep developers from tailoring industrial park design and utilities. Instead flexibility and solidity could be gained, and the offer of business space could be diversified, supported by a persevering issuing procedure to join similar and matching energy profiles. Energy management on industrial parks in Flanders has only recently started but is expected to gain professionalism. However further research is needed on this flexible design and thermal planning.
\end{abstract}

(C) 2011 Elsevier Ltd. All rights reserved.

\section{Contents}

1. Introduction

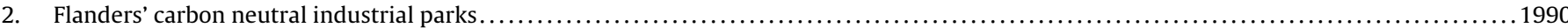

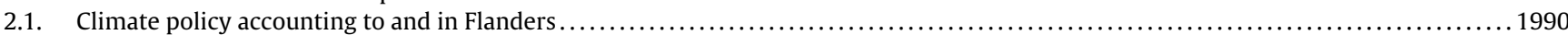

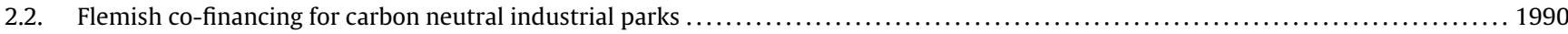

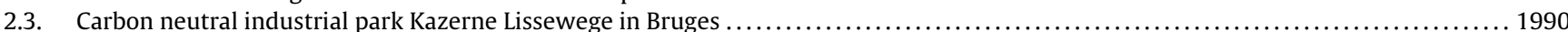

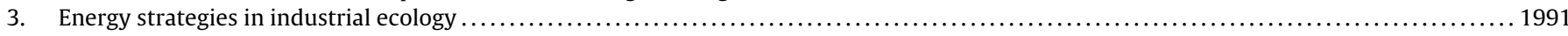

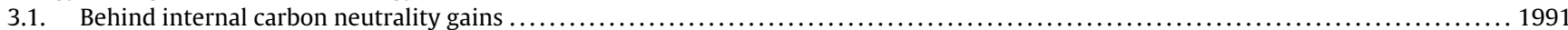

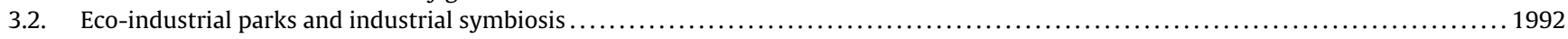

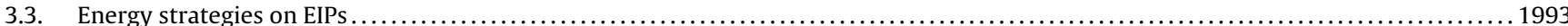

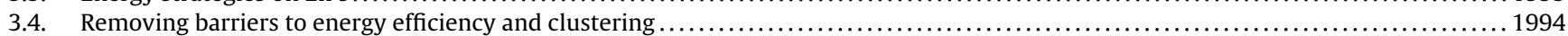

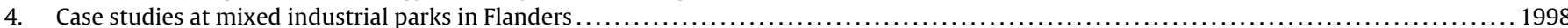

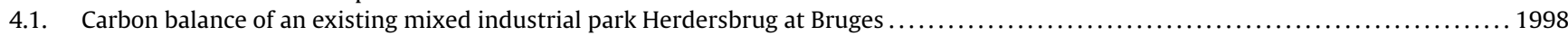

4.2. Collective energy production on a new mixed industrial park Sappenleen at Poperinge....................................

\footnotetext{
* Corresponding author. Tel.: +32933132 59; fax: +3293313269.

E-mail addresses: mrb@ugent.be (T. Maes), chantal.block@groept.be (C. Block), ann.pisman@ugent.be (A. Pisman), bjorn.verhofstede@ugent.be (B. Verhofstede), frederik.vandendriessche@ugent.be (F. Vandendriessche), lieven.vandevelde@ugent.be (L. Vandevelde).
} 


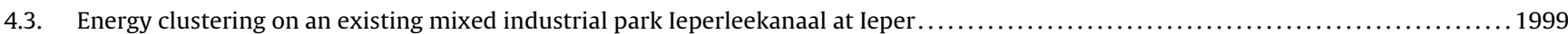

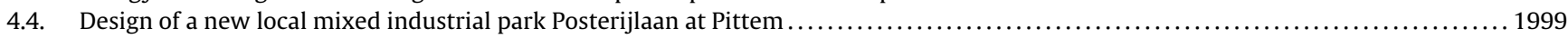

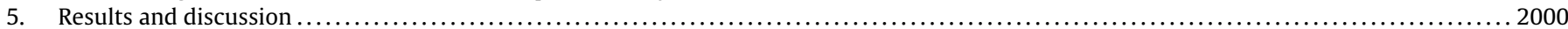

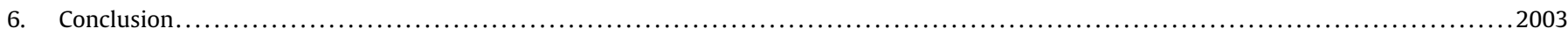

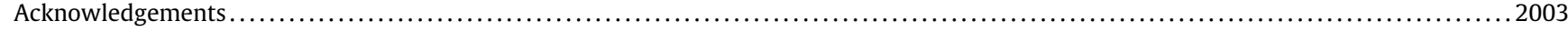

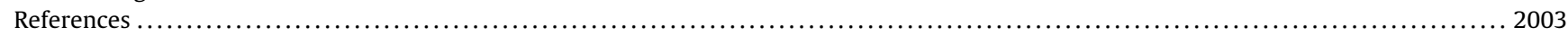

\section{Introduction}

Climate change forces for a fast global socio-economic transition. What outcome this next industrial revolution ultimately will have is under great uncertainty. Yet it is clear that business and governments profiling in carbon neutrality is part of the inclination.

Climate change effects are undeniable, effecting natural ecosystems but also societies [1-3]. While mainstream attention has focused now on the $2{ }^{\circ} \mathrm{C}$ global warming limit, knowledge on climate change builds up to the conclusion that severe global warming effects will already be happening at lower temperature rises [4]. Further, the uncertainty on thresholds for abrupt and irreversible changes and carbon feedbacks feeds concern [1]. Latest statistical sources point to an atmospheric concentration of $435 \mathrm{ppm} \mathrm{CO}_{2}$ eq. related to a preindustrial concentration of $280 \mathrm{ppm} \mathrm{[5,6].60 \%}$ of the total annual global anthropogenic greenhouse gas emissions (GHG) originate from fossil fuel burning and their growth correlates to the most pessimistic 2007 IPCC scenarios [7-9]. However, to limit global average warming under $2^{\circ} \mathrm{C}$, global emissions need to decline rapidly from 2020 on. The average annual percapita emissions will have to be reduced to well under 1 metric ton $\mathrm{CO}_{2}$-eq. by 2050 , being $80-95 \%$ below the per-capita emissions in developed nations in 2000 [1,2]. The longer action is postponed, the stronger emission cuts have to be taken, the more costly it will be [5]. Researchers even advice a net emission take up has to be searched and strived for [10]. Parallel to mitigation, adaptation to unavoidable climate change effects is stressed on. From a Western perspective, mitigation must be viewed as an investment, with manageable costs, to avoid the risks of severe climate change consequences. Based on 2001 IPCC TAR data, the total cost of a business as usual scenario would be equivalent to a $20 \%$ reduction in global per-capita consumption. Instead, annual costs of stabilisation at $500-550 \mathrm{ppm} \mathrm{CO}_{2}$-eq. are estimated at $1 \%$ of the global gross domestic product, while positive challenges for competitiveness and opportunities for growth can come along [5]. For the poorest and most unstable countries, which will be effected the most by climate change, life itself is at stake and (extended) severe social instability is threatening [3].

In this context of growing " $\mathrm{CO}_{2}$ " awareness, numerous businesses in the West claim full carbon neutrality or strive for carbon neutral premises. Others offer zero emission services as freight or people transport. A growing number of companies sell green products such as green electricity and green gas (i.e. using renewable energy sources). Lots set goals to reduce carbon emissions drastically, while some are even pushing their suppliers to follow [11-18]. Almost 20 years after Tibbs [19], associated to Arthur D. Little and Global Business Network, set the corporate agenda for greening business, now multiple major consulting firms point to corporate environmentalism as the defining issue. McKinsey \& Company believes "the shift to a low-carbon economy is already under way and that business must get ready for it [...]; the value at stake over the next two decades and beyond is going to be enormous" [20]. "The smartest companies will understand that creating products whose production results in reduced carbon emissions and fossil fuel consumption is the only way they can be sustainable. The stubborn ones will go out of business." Deloitte says [13]. "We are approaching a tipping point at which the issue's importance to business performance and investors will escalate. The equity market is only just beginning to reflect the magnitude of change that lies ahead." according to Goldman Sachs [21]. "Shareholder value will be created or destroyed the way a company manages its carbon emissions and exposure to climate change regulations" [18]. Despite, or perhaps thanks to the financial and economic crisis since 2008, the 2009 Ernst \& Young business risk report puts 'radical greening' at 4th place in the top ten corporate risks [22]. Sustainability pays as A.T. Kearney found out that "during the current economic slowdown, companies that show a 'true' commitment to sustainability appear to outperform their industry peers in the financial markets" [23]. After climate change, now also biodiversity gains a positive interest from business [24]. With or without governments' moving, companies should not wait. They must proactively raise the carbon productivity of their current assets and pursue new business growth by developing new products, services, business models and interfirm business connections in order to introduce the green products and services needed in a low-carbon economy [20].

Governments must follow and support the changing internal market potential, in order to keep up with international competitiveness in low-carbon economy. "The Green Race is on between countries to transform to low-carbon economies and to become the leading supplier of resource efficient technologies and solutions. If you want to win, transform your home market to build competences and scale." Stigson says, president of the World Business Council for Sustainable Development [25]. "Early action will provide our industries with a vital head start. [...] It is a policy for jobs and growth, energy security and climate risk. Most of all, it is a policy for Europe's future." the UK climate change secretary, the German and the French environment ministers indicate in the Financial Times [26], and backed up by chairmen and CEO's from 27 companies in the same newspaper 6 days later as a reaction upon more conservative reactions from business [27,28]: "The EU's future competitive advantage lies in encouraging and enabling its businesses to help drive the transformational change that will occur in the world economy within the next couple of decades, not to hide from it." Between June 2008 and February 2009, governments worldwide committed to invest more than 430 billion US dollars in climate change stimulus packages, tax credits, grants and incentives, and enacted 250 climate change regulations [29,30]. In every continent, there are large cities attempting to tackle climate change faster than countries do, through local sustainable energy and climate action plans [31-33]. Already in 1996 the European Council decided global warming should be limited to $2{ }^{\circ} \mathrm{C}$ above pre-industrial values, finally followed by the international society on the COP15 end 2009 [34,35]. In the EUs wake, Belgium and its regions are transforming EU directives into national and regional legislations and are experimenting with innovative environmental stimuli. Introduced in 2007 only 'carbon neutral' new industrial developments remain financially supported by the regional government of Flanders. Since then around 20 projects have been initiated.

This article discusses the experimental program in Flanders and adds inspiration for further advancement coming from theory and practices of industrial symbiosis and eco-industrial parks. In the following, Section 2 introduces the Flemish policy for carbon neutral 
industrial parks and illustrates with an example of first field practice. Section 3 confronts the Flemish focus with regional scientific greenhouse gas emission analysis, and searches for specific energy strategies to enhance the current low-carbon approach. Section 4 illustrates with case studies of first applications in further carbon footprint optimisation initiated within development and management practice of industrial parks in Flanders. As a result, Section 5 brings together theoretic concepts and field practice to introduce an integral method for energy management on industrial parks, and highlights practical barriers and possible solutions.

\section{Flanders' carbon neutral industrial parks}

As Belgium is an EU member state, climate policy in Belgium is grafted onto the European Union's climate strategy. Yet, the federal level and the regions of Belgium are equally responsible for reducing greenhouse emissions. The "carbon neutral industrial parks" are an initiative of the Flemish region, introducing the carbon footprint of companies into the quality requirements for industrial parks. Although the initial focus of the Flemish government remained rather low profile, local initiatives already embed the "carbon neutrality" condition into a more sustainable energy strategy.

\subsection{Climate policy accounting to and in Flanders}

The European bodies have been committed to take the lead in climate action, both by immediate action internally and international lobbying [36]. The European Commission launched the Energy and Climate Package for 2020 (20/20/20-package): a commitment to reduce consumption of primary energy by $20 \%$ compared to forecasts for 2020 [37], a renewable energy's share of primary energy consumption of $20 \%$ [38], and a $20 \%$ reduction of greenhouse gas emissions related to the emission level of 1990 (30\% in case of international agreement) [36] aiming at all energy consumption sectors including the built environment, transport, industry and the energy sector. The European Union Emissions Trading Scheme (ETS) [39], being a key instrument in the European climate change strategy, covered $45 \%$ of all $\mathrm{CO}_{2}$ emissions in the EU in 2007 and will be further strengthened and extended [40]. Member states are also urged to take national actions in order to attain the 2020 goals. National and regional legislations, such as in France and Flanders, and increasing debates within the Union, illustrate the gradual introduction of fiscal penalisation of carbon emission [26,41-43].

Belgium has been assigned a first 7.5\% GHG emission reduction under the Kyoto Protocol [44]. Following the EU 20/20/20-package, the country needs to reduce $15 \%$ by 2020 in relation to the emission level in 2005 for all sources not falling under the ETS [45]. All EU installations falling under the Scheme need to reduce 21\% together by 2020 in relation to emissions in 2005 [40]. Policies and measures to reduce GHG emissions are distributed over the federal and regional governments. Tax incentives are introduced by the federal level, while the regional governments of Belgium focus on environmental protection, mainly rational energy use and new energy, including renewables but excluding nuclear. Some important measures are the introduction of green certificates (feed-in tariffs) for renewable electricity, investment support for rational energy use and renewables, energy performance standards for buildings, environment permits (restrictions, introduction of best available technologies) and voluntary agreements with industry (covenants) [44]. One of Flanders' measures focuses on industrial sites, which is the subject of this article.

\subsection{Flemish co-financing for carbon neutral industrial parks}

A carbon reduction program specific for industrial and business parks ${ }^{1}$ has been introduced by the Flemish government as an important policy focus since 2007. Grants to park developers and managers are guided by driving forces built upon carbon emission reduction and sustainable energy policy measures. A "carbon neutrality" amendment is incorporated in the act concerning public co-financing of the (re)development of industrial sites in Flanders. Yet carbon neutrality covers many overtones. In its widest meaning, it refers to the broader climate neutrality, meaning a zero emission of all substances causing a greenhouse effect, such as $\mathrm{CO}_{2}, \mathrm{CH}_{4}, \mathrm{~N}_{2} \mathrm{O}$, halogenated hydrocarbons, $\mathrm{SF}_{6}$, black carbon, $\mathrm{CO}$, volatile hydrocarbons in the first place [46], emitted due to energy consumption, through processes and transport, embedded in infrastructures, machinery, raw materials, products, etc. In this case, the prerequisite of a 'carbon neutral industrial park' narrows down to a zero net $\mathrm{CO}_{2}$ emission of the electricity consumption (during the operational phase of energy production installations). Direct use of green electricity (renewable energy) or compensation of carbon emissions is the prime objective. The responsibility lies with the park developer to pass on this obligation to the companies located on the concerned park and to enforce if necessary. If not, the park management could be obliged to repay its public financial support $[42,47,48]$.

A small survey carried out by the Flanders' Chamber of Commerce and Industry, Voka, indicated that the electricity share covers $50-90 \%$ of the primary energy use at an $\mathrm{SMEs}^{2}$ site [49]. Moreover, in case of electricity production $\mathrm{CO}_{2}$ is considered an acceptable target, as it covers more than $99 \%$ of at least the greenhouse gas emissions $\left(\mathrm{CO}_{2}, \mathrm{CH}_{4}, \mathrm{~N}_{2} \mathrm{O}\right.$, halogenated hydrocarbons, $\left.\mathrm{SF}_{6}\right)$ due to electricity production, transport and distribution in Flanders in 2006 [50]. Unfortunately the electricity consumption share of the total greenhouse substances emission for premises, organisations and across full value chains can be low for many businesses [51]. Therefore the carbon neutrality requisite can be remarked only as a starting point, an introduction to a green image. It may however also be a stimulus for (further) corporate responsibility in the environmental and climate change issue. Certainly, the creation of an activated energy conscience is considered necessary in order to attain a cost-effective corporate energy strategy that is part of the carbon neutrality condition. Hence the co-financing regulation is narrowed down to a welcome igniting tool by redirecting the focus from carbon neutrality of the electricity consumption to the energy use itself, the energy efficiency and even productivity. It may induce a sustainable energy strategy, that is characterised by the Trias Energetica concept ${ }^{3}$ focusing first on process optimisation and energy efficiency and in a second step reaching for renewable energy use or carbon neutrality [52]. However, to ensure global emission reductions, carbon footprint calculation and optimisation of entire premises, organisations and value chains should also be encouraged, in order to detect and address the key sources first [51].

\subsection{Carbon neutral industrial park Kazerne Lissewege in Bruges}

Industrial park Kazerne Lissewege of the West Flanders Intermunicipal Association ${ }^{4}$ (wvi) is one of the first realisations under the new Flemish carbon neutrality regulation and serves as an

\footnotetext{
1 In the following we will use the term 'industrial park' to encompass both.

2 Small to medium sized enterprises.

${ }^{3}$ Reduce energy demand - Use renewables - Produce \& use fossil fuel as efficiently as possible. http://www.triasenergetica.com/.

${ }^{4}$ West-Vlaamse Intercommunale, www.aib-net.org.
} 
example of field practice, as it extents already the carbon neutrality condition in its strict sense to encompass the Trias Energetica principle. It is a reconversion of an old army barrack of 2.3 ha, now offering 9 building lots, 11 warehouse and 7 office modules for small companies.

It is wvi's view to install the carbon neutrality requisite as an operational and strategic benefit for its companies. Therefore it focuses on a rational energy use prior to carbon neutrality. Wvi has designed a spatial plan focused on compact building and we have developed a set of guidelines, focusing on key mitigation technologies ([2] Table 4.2) and invoking a cost-cutting energy strategy in buildings and machinery:

- Newly built and renovated warehouses have to meet almost 30\%, and offices and dwellings $40 \%$ stronger isolation standards than the Flemish building standard (started with [53,54]).

- Offices also have to meet $40 \%$ stronger energy standards, dwellings $25 \%$ in relation to the Flemish standard.

- The use of active cooling is only allowed after installing protection against excessive solar irradiation and analysing passive cooling strategies.

- Lighting appliances should meet minimum efficiency criteria.

- A quick scan detects possible investments in the machinery for core activities. Investments characterised by a pay-back period of maximum 3 years should be executed.

Secondly businesses can decide on different options for attaining the carbon neutral electricity: purchase of green electricity (from renewable sources), self-production of green electricity, individually or collectively, purchase of Renewable Energy Guarantees of Origin (RES-GO), ${ }^{5}$ purchase of emission credits issued under the Clean Development Mechanism or Joint Implementation programmes and meeting the Gold Standard, ${ }^{6}$ or finally purchase or production of blue electricity (i.e. using cogeneration) if all produced electricity also qualifies as green electricity (through using renewable fuel or purchasing RES-GOs) or if all emissions are compensated. All electricity consumed and produced should meet carbon neutrality.

Next to the requirements primarily focusing on the building phase, wvi's 'park management"7 is specialising in rational energy use and sustainable energy technologies. Together with Agentschap Ondernemen, ${ }^{8}$ wvi introduces the quick scan and guides companies so as to implement the carbon neutrality requirements in a cost-effective and strategically sound manner. Moreover, the park management insists on companies picking the fruits of the upcoming low-carbon economy by developing and distributing green products and services.

The first results are promising: businesses interested for location as well as building firms react positively on the extensive support from the wvi and accept the energy conditions, which direct them towards the future energy and building landscapes. Certainly, the 'carbon neutrality' conditions activate attention to the topic, of businesses as well as within the integral team of the industrial park developer and management.

As wvi, other industrial park developers set up a "carbon neutrality" strategy focusing on the Trias Energetica principle. The Intermunicipal Association Leiedal [55], the Provincial Development Agency of Antwerp [56] and Veneco ${ }^{2}$ [57], a park developer in the region of Ghent, play a pioneer role. It is believed that many

\footnotetext{
5 http://www.aib-net.org/.

6 http://www.cdmgoldstandard.org/.

7 A group of 'park managers' keeps close contact to the businesses during the issuing process and exploitation.

${ }^{8}$ A Flemish agency for enterprising, http://www.agentschapondernemen.be/.
}

actors will follow, even on short notice, as markets evolve to greater energy efficiency. Besides guidelines will become more stringent, even more demanding, thus sidetracking developers and managers who do not tag along.

\section{Energy strategies in industrial ecology}

The legally binding "carbon neutrality" initiative for industrial park developers and managers in Flanders has initiated first steps in an issuing process of industrial land, taking along the carbon footprint of companies. Multiple park developers embed the green electricity or emission compensation condition in a Trias Energetica strategy, demanding rational energy use in buildings and installations in addition. However, these conditions remain internally focused, while industrial symbiosis promises environmental gains in interfirm clustering to reach well behind possible internal optimisation. In this section, the concept of industrial symbiosis is situated and explored, focussing on energy strategies in interfirm clustering. First, the need for extending the current Flemish 'carbon neutrality' focus is identified.

\subsection{Behind internal carbon neutrality gains}

Multiple 'carbon neutrality' initiatives on industrial parks stimulate low energy building, energy efficiency and renewable energy production (see also Canadian initiatives: Innovista EcoIndustrial Park [58] and Taiga Nova Eco-Industrial Park [59]). In the future, buildings will increasingly be "passive"9 and strive to energy autonomy. New allotments should be designed for compact buildings and consider climate parameters, such as irradiation, wind, urban heat effects,... Industry will endeavour the maximum of process optimisation and energy efficiency, and energy production will switch to renewables as quick and as far as possible. This is conditional to meet the energy efficiency rise of $20 \%$ as dictated by the EU Energy and Climate package [60].

However, scenario calculations by the Flemish Environment Agency (VMM) expect only a $12 \%$ reduction of GHG emission by 2020 and 36\% reduction by 2030 being accomplished in Flanders. Society is in need of more structural change, of a transition reaching further than just product and process optimisation [60]. In the building sector, energy autonomy should be strived for individually, indeed, but also collectively. A group of dwellings and other buildings is perfectly fit for collective local electricity and heat production and distribution. Moreover, industrial parks should become energy autonomous on local renewable energy production and operate in industrial clusters. New business models are to be introduced developing new product-service combinations, in accordance to the B1 SRES 'service and information economy' scenario from IPCC [2].

Without structural changes Flanders could be threatened, not only by a climate crisis but also by a new economic, structural crisis. The Goldman Sachs Group [21] analysed "that a value of US\$60/t placed on all direct carbon emissions would result in $\sim 20 \%$ of the cash flow of carbon intensive industries moving from less- to more- carbon efficient companies. The secondary effects of higher input costs on industries reliant on carbon intensive materials or energy will prove very significant as they feed through industry value chains, as will the changing end-demand pressures companies face". The Environmental Exploration 2030 of the VMM investigated the possibilities of reducing GHG emissions within industry and energy production. The study starts from an expected

\footnotetext{
9 http://www.passiv.de/.
} 
carbon price of $€ 77,6 / \mathrm{t} \mathrm{CO}_{2}$ from 2020 to $2030,{ }^{10}$ needed to cope with a $50 \%$ GHG emission reduction by 2030 and a $60-80 \%$ emission reduction by 2050 in the EU-27. Flemish installations falling under the European Emission Directive [39,40] will not reduce their emissions under the level of 2006. VMM [60] calculated that it is more economically sound to meet the European and expected global emission goals by purchasing emission credits in other regions and countries of the European Union or abroad. This means that the competitive strength of Flanders could be heavily damaged unless a more structural transition in the socio-technical system is accomplished. By eliminating the extra costs for the purchase of emission credits, even allowing selling credits and earning more profit when located in Flanders, the region could instead gain competitive strength.

"To help companies benefit from the coming transition, their managers should carefully begin to reposition them for a lowcarbon landscape" [20]. The same counts for countries offering a competitive or uncompetitive operational and physical framework for low-carbon businesses to develop, to compete on a local and/or international market and finally to grow. Therefore, the physical framework, or industrial parks, should not only focus on internally directed energy and emission constraints. In this case, the existence of an industrial park entity does not produce an essential added value concerning the energy or carbon profile of the companies located at the park. Internal directed constraints only speed up the evolution of reducing carbon footprints, stimulates lowcarbon investments, and hopes to induce an early movers benefit, since eventually it all will be implemented due to upcoming European directives and global protocols. Still the physical framework, installed for many years for companies to operate in, should also be compatible with, even invite, the long term structural changes needed to be competitive in a low-carbon economy and provide the utilities and space to do.

According to Roberts [61], there are indeed two directions in installing greener industrial parks (Fig. 1).

- 'Green industry parks' include a range of enterprises that apply cleaner production technologies, process much of their waste and/or reduce the emission of greenhouse gases, in situ.

- 'Integrated eco-industry parks' are specifically designed to encourage the development of symbiotic relationships between companies to lower environmental impact.

Consequently, the Flemish 'carbon neutral' industrial sites could be denoted as an attempt to evolve into 'green industry parks', while a long term physical framework should prepare for industrial clustering, according to the Flemish Environment Agency. In other words, carbon neutral industrial parks should go for 'integrated eco-industry parks' instead of 'green industry parks', but the latter can of course be integrated in the first. Aro [62] supports this thought: "Much of the discussion on GHG mitigation has been targeted at international or national levels where sectoral approaches illuminate the origins of $\mathrm{CO}_{2}$ emissions and are useful for general industrial GHG policymaking. To achieve real results in the mitigation policy, more and more activities must be set at local or regional levels. That is where the real results in tackling of climate change will take place. At a local or regional level, successful policy means cooperation among different industries, not only among specific industrial sectors. This is because at the local level, there are many industrial sectors and one sector may have only one or very few separate companies. Furthermore, cooperation is needed between indus-

\footnotetext{
10 Carbon spot price today around 13 euro per ton $\mathrm{CO}_{2}$ [114] BlueNext. http://www.bluenext.eu/. August 26th, 2010.
}

try and other sectors of society. A cross-sectoral approach is a must."

\subsection{Eco-industrial parks and industrial symbiosis}

The dawn of environmental awareness in the industrial metabolism' [63] has lead to the invention of eco-industrial parks (EIP). Developing such an industrial site, multiple strategies for sustainability are applied. Central to the original concept is the introduction of industrial symbiosis primarily on an EIP scale, which "engages traditionally separate industries in a collective approach to competitive advantage involving physical exchange of materials, energy, water, and/or by-products" [64-67]. Today clustering of companies on the broader range of the 3P triangle (people, planet, profit; [68]) is aimed for [69]. In addition EIPs apply principles of design for the environment, pollution prevention, and sustainable architecture, construction and planning [65]. Multiple definitions have been formulated, for example (for a discussion, see Côté and Cohen-Rosenthal [70]):

- "A community of manufacturing and service businesses seeking enhanced environmental and economic performance through collaboration in managing environmental and resource issues including energy, water, and materials. By working together, the community of businesses seeks a collective benefit that is greater than the sum of the individual benefits each company would realise if it optimised its individual performance only. The goal of an EIP is to improve the economic performance of the participating companies while minimising their environmental impact. Components of this approach include new or retrofitted design of park infrastructure and plants, pollution prevention, energy efficiency, and inter-company partnering. Through collaboration, this community of companies becomes an 'industrial ecosystem" [65].

- "An eco-industrial park is an industrial system which conserves natural and economic resources; reduces production, material, energy, insurance and treatments costs and liabilities; improves operating efficiency, quality, worker health and public image; and provides opportunities for income generation from use and sale of wasted materials" [71].

Introduced in the 1990s, EIPs have gained global interest and imitation: in Central and South America, in Europe, in Asia, in Oceania $[61,67,70-76]$. The concept states industry to be able to operate more environmentally friendly in cluster than individually. This explains the interest of the Flemish Environment Agency in its aim to reduce carbon emissions from industry. UK's National Industrial Symbiosis Program (NISP) also translates the industrial symbiosis concept into deliverables, gathering a network of 12,500 companies from every sector of which a 100 multinationals but more than 90\% SMEs and micro companies. NISP focuses on materials, water, energy, logistics, expertise and asset utilisation. Five years after startup they have accomplished a reduction of 6 million ton of $\mathrm{CO}_{2}$ through input, process, fuel, transport, disposal and energy savings [77]. Their focus is not restricted however to exchange opportunities within an industrial site but expands to a regional industrial metabolism. For materials integration this is a necessary condition to find enough possible connections and thus to become a practical concept: a region provides a broader market thus increased opportunities for exchange, more potential partners, and alternative partners in case business conditions and companies change which is inevitable; waste and material costs, and transport costs are too low for industrial symbiosis to function as a prime localisation criterium and thus to stimulate colocation of companies [61,65,78-80]. Moreover, the regional focus reflects back to the original idea of Frosch and Gallopoulos who success- 


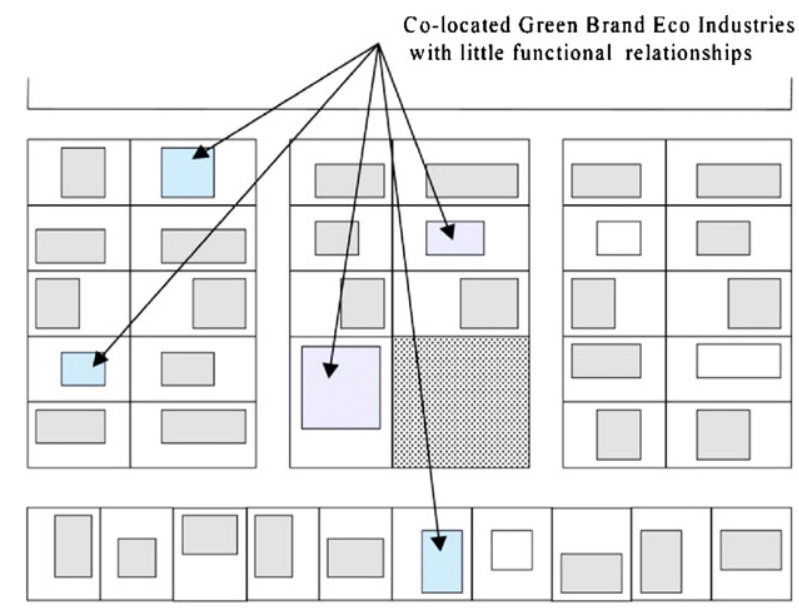

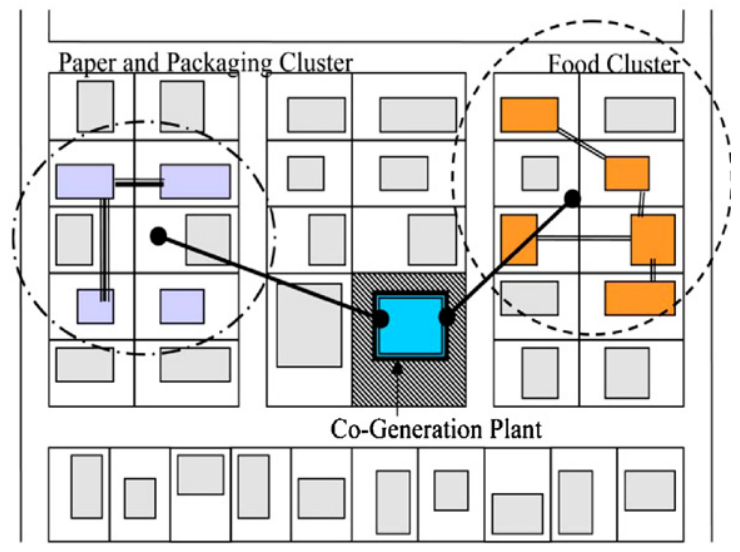

Eco Industries with clustering and common user facilities

Fig. 1. Green industry parks versus integrated eco-industry parks [61].

fully introduced the 'industrial ecosystem' [63,81]. Manufacturing processes transform circulating stocks of materials from one shape to another. All material flows, from production and consumption, must be taken along, not just byproducts or waste from neighbouring businesses. It leads to the concept of 'industrial ecology' prior to eco-industrial parks, of which Jelinski et al. [82] give an eloquent description. For a discussion, see also Lifset and Graedel [83] and Ayres [84].

\subsection{Energy strategies on EIPS}

Industrial symbiosis and certainly industrial ecology thus requires at least a regional basis and cannot be restricted to an industrial park. However, interfirm energy-flow integration is fundamentally different from interfirm material-flow integration [85]:

- certain kinds of end-use energy, e.g. electricity and process heat, can hardly be stored, necessitating simultaneous production and demand;

- linking energy flows often requires the installation of specific hardware such as steam pipes, resulting in considerable investments and heat losses, which increase with the length of the pipeline, thus linking heat flows in an economically and technically feasible way requires a close spatial proximity;

- material as an exchangeable medium is much more diverse than energy is.

Energy clustering is a local optimisation problem which is believed to provide strong benefits. Corporate advantages could be found in different classes, first of all in a reduction of capital and operational expenditures:

- in reduced installation costs through economies of scale, higher production efficiency of large scale installations (therefore lower capacity needed), accessibility to more efficient techniques, outsourcing of energy installation investments;

- in reduced fuel costs like a reduced energy price from bundling energy demand (higher volume, more even energy consumption (and production) load curve), through improved attainability of renewable energy use, through exchange of useful energy losses;

- in reduced maintenance costs through economies of scale, increased attainability of professional services, lower idle time losses through better maintenance;

- in reduced net costs as lower net unit costs through bundling energy distribution system take-up (and injection) (higher volume, more even load curve), through increased attainability of energy autonomy;

- and/or in reduced taxes and through subsidies.

Energy security could also be increased through reduced dependence on energy market prices, higher operational reliability or outsourcing. Next, the attainability of cleaner energy production and therefore a lower carbon footprint could be increased though clustering, which could improve the companies' positions in production chains and improve image. At last, companies could have a cleaner working environment and reach further for corporate social responsibility.

For Beyene [86] energy efficiency should be the central orientation when developing eco-industrial parks as the energy, water and material symbiotic maximisation at one time is too complex to handle. "The manufacturing park optimised for maximum energy efficiency [...] can then work hierarchically toward adopting more useful performance and waste-related parameters as secondary objectives [...]" According to Beyene, all relevant energy resources must be investigated, such as electric energy, steam and hot water, compressed air, waste exhaust heat, and chilled water." To deliver this energy integration, Aro's [62] classification of companies could serve as a first aid tool: building energy users (HVAC, lighting and low energy consuming processes), process heat users, process electricity users and direct combustion users (Tables $1 \mathrm{a}$ and $1 \mathrm{~b}$ ). There are also few energy statistics available for SMEs, which show high variability however (Table 2).

Heeres et al. [75] put the priority on the establishment of utility sharing rather than on exchanges in material, water and energy: "Pollution prevention utility sharing (like combined treatment of waste water or combined cogeneration of heat and power) proved to be easier to implement than material exchanges. [...] For utility sharing disadvantages of interfirm co-operation (expected economic gains may need to be shared, co-operation may add additional expenses and may generate new risks like uncertain supplies) may be less than for material exchanges. Seen from this perspective, extended pollution prevention may very well be an indispensable first step in the direction of establishing industrial networks, where effluents of one process serve as the raw materials for other processes."

An especially promising evolution in electricity utilities are the so-called microgrids to install the appropriate utilities on industrial parks. Indeed, the highly supported distributed energy generation, or more general the future distributed resources (distributed energy generation, storage, management), require distribution networks being able to actively manage power flow and to allow 
Table 1a

Energy consumption classification of companies and processes [62].

\begin{tabular}{|c|c|}
\hline Form of energy use & Description \\
\hline Building energy users & $\begin{array}{l}\text { Small amounts of electricity and heat are used in the production. HVAC and } \\
\text { lighting are clearly the main energy consumers. Assembly lines, the } \\
\text { production of equipment and machines are typical industrial sector } \\
\text { representatives for this category. In general, many industries which are often } \\
\text { described as non-energy intensive can be considered building energy users. }\end{array}$ \\
\hline $\begin{array}{l}\text { Major users of electricity for } \\
\text { process/production }\end{array}$ & $\begin{array}{l}\text { Electricity use in process/production is clearly bigger than the building } \\
\text { electricity consumption. Typical branches of industry falling into this category } \\
\text { are pulp and paper, metal production, production of plastic products and glass } \\
\text { making. }\end{array}$ \\
\hline $\begin{array}{l}\text { Major users of heat for } \\
\text { process/production }\end{array}$ & $\begin{array}{l}\text { Heat use in the process/production is clearly bigger than the building heat } \\
\text { consumption. Heat means energy forms which are transmitted by pipes such } \\
\text { as water, steam and hot oils. Typical branches of industry belonging to this } \\
\text { category are pulp and paper, dairies, part of the textile industry, chemical } \\
\text { industry, production of rubber products. }\end{array}$ \\
\hline Direct combustion users & $\begin{array}{l}\text { In some applications, the product can be heated directly or indirectly by fire } \\
\text { and/or flue gases. Especially natural gas is good in many applications. Typical } \\
\text { representatives are cement and lime production, glass and brick production, } \\
\text { bakeries and production of metals. }\end{array}$ \\
\hline
\end{tabular}

storage of energy for later use [87-90]. A promising strategy to fulfil this goal is to sector the entire distribution system into 'microgrids' being able to actively manage local distributed resources and also stand ready to support the upper connecting grid in delivery of energy and net support. Microgrids will be designed to operate interconnected to the distribution system but also autonomous. Therefore microgrids are demarcated to cover all energy consumption with distributed generation or stored energy. Hence, low-carbon industrial parks should be prepared with such an intelligent microgrid.

Moreover, as the numerous technical, spatial and financial barriers can prohibit companies from investing in sufficient individual renewable power for their operation - roof or ground surface can be inadequate for installing equipment or sufficient capacity, spatial requirements can narrow the choice in distributed generation systems, based on spatial quality industrial parks can have predefined and thus limited places for installing renewable energy capacity, etc. - the concept of microgrids serves as an inspiration in which the industrial park as a whole can be explored to produce the necessary energy consumed by all companies, instead of viewing each company with its energy consumption profile and energy production potential separate. Hence industrial parks are invited to prepare local electrical networks linking local energy producers and consumers with little cost for energy transfer. Research and innovation is needed to allow these low-cost networks and to setup a specific regulation. Even an adapted tariff structure is required, covering all costs and benefits of increasing autonomy and eventually delivering ancillary services to the distribution network. To stimulate industrial clustering for companies themselves, local (renewable) energy coverage, demand and storage management has to be stimulated: short energy paths and storage will have to be remunerated.

A last input to energy strategies on industrial parks is offered by Lambert and Boons [74] who oppose to the automatic and unique attention for industrial clusters concerning eco-industrial parks from another point of view. A growing number of mixed industrial parks holds characteristics that are completely different from traditional industrial parks. Mixed industrial parks are characterised by a strong diversity in business sectors (production, manufacturing, logistics, services, depots, wholesale, retail, recycling, etc.), in scale (numerous small and medium sized enterprises, small to medium business parks as well), even in function (business, residential, leisure, etc.) and by a rapid change in population. "The enterprises experience no advantage of each other's vicinity, there might be competition on the one hand, indifference and differ- ence in interest on the other hand. Coherence is poor" [74]. Mixed industrial parks require a broader strategy to sustainability. Key issues are the choice of location and the park's spatial design, the installation of a structural platform for inter-company deliberation, and site or park management. Their presence or availability is recognised to lead to various PPP-projects, including the collective purchase of services and investment in infrastructure [69,74,91,92]. However, interfirm cooperation in energy is a type of industrial clustering that is of interest both at traditional industrial parks and mixed industrial parks. In casu, it is of interest at energy-intensive companies and non energy-intensive companies, and it may even physically bind the two. Lambert and Boons [74] proof the natural tendency on traditional industrial sites for process integration, within a single company but also exceeding the company's borders. They expect interest in collective energy purchase and production, but less in heat exchange on mixed industrial parks. "Although some resident industries in the food or process sector set residual heat available, the need for the exchange of residual products is considered of minor importance. Most of the interest in this field is in collective purchasing of utilities such as energy, the collective recollection and processing of packaging materials and solid waste, and, possibly, the collective generation of energy. The firms want to contribute only on a voluntary base."

\subsection{Removing barriers to energy efficiency and clustering}

Beyene [86] as well as Lambert and Boons [74] call for an adequate "coupling" of companies into one or more thematic energy clusters, based on the energy profiles and preferences of the businesses. Heeres et al. [75] would introduce physical integration through utility sharing. On the other hand as Lambert and Boons [74] already suggest, EIPs, industrial symbiosis and energy integration cannot be planned too strongly, nor without business engagement. Energy clustering cannot be forced upon businesses but it should be stimulated - if the sustainability of the energy supply and consumption can be increased - facilitated - if aimed for - and barriers to clustering should be removed or at least evaded. A personal and frequent communication of the park developer and manager is needed in the first place to convince businesses to locate on its park, and second to support, facilitate and stimulate companies to reach for low-carbon building and operation. SMEs may strongly need the energy expertise of the park developer or manager. The latter also keeps a helicopter view, yet is closely associated to identify clustering opportunities together with the located businesses and possible external connections. Additionally, specialised 
Table 1b

Energy use categories for different industries (examples of Finnish context) [62].

\begin{tabular}{|c|c|c|c|c|}
\hline Industry & $\begin{array}{l}\text { Significant building energy } \\
\text { user }\end{array}$ & $\begin{array}{l}\text { Significant process electricity } \\
\text { consumption }\end{array}$ & $\begin{array}{l}\text { Significant process heat } \\
\text { consumption (water, steam, } \\
\text { hot oil) }\end{array}$ & $\begin{array}{l}\text { Significant process heat } \\
\text { combustion user (oil, } \\
\text { natural gas and solid fuels) }\end{array}$ \\
\hline Manufacture of food and beverages & $\begin{array}{l}\text { If the processes can be } \\
\text { managed with electrical } \\
\text { heating, the usage of district } \\
\text { heating is reasonable. If a } \\
\text { boiler is needed for the } \\
\text { process, it is often used to heat } \\
\text { up the buildings as well. }\end{array}$ & $\begin{array}{l}\text { Electrical ovens } \\
\text { Cooling } \\
\text { Grinding machines } \\
\text { Mixing machines } \\
\text { Concentration plants } \\
\text { Pumping }\end{array}$ & $\begin{array}{l}\text { Cooking } \\
\text { Washing } \\
\text { Sterilization, acid and alkali } \\
\text { washes Pasteurization } \\
\text { Dewatering }\end{array}$ & Baking and resing \\
\hline Manufacture of textiles & Typical building energy users & $\begin{array}{l}\text { Drying } \\
\text { Production machines }\end{array}$ & $\begin{array}{l}\text { Dye works } \\
\text { Manufacturing of cheeses } \\
\text { Manufacture of special textiles } \\
\text { Drying }\end{array}$ & $\begin{array}{l}\text { Drying - the number of } \\
\text { factories using direct } \\
\text { combustion is diminishing }\end{array}$ \\
\hline $\begin{array}{l}\text { Manufacture of wearing apparel; } \\
\text { dressing and dyeing of fur }\end{array}$ & Typical building energy users & Machines and devices & $\begin{array}{l}\text { Small steam generators are } \\
\text { able to provide enough steam } \\
\text { for pressing }\end{array}$ & \\
\hline $\begin{array}{l}\text { Tanning and dressing of leather; } \\
\text { manufacture of luggage, } \\
\text { handbags, saddlery, harness and } \\
\text { footwear }\end{array}$ & Typical building energy users & Drying drying & $\begin{array}{l}\text { Low temperature level water } \\
\text { heating and leather }\end{array}$ & \\
\hline $\begin{array}{l}\text { Manufacture of wood and of } \\
\text { products of wood and cork, } \\
\text { except furniture; manufacture of } \\
\text { articles of straw and plaiting } \\
\text { matter }\end{array}$ & $\begin{array}{l}\text { Typical building energy users } \\
\text { Not all of the buildings are } \\
\text { heated }\end{array}$ & $\begin{array}{l}\text { Wood processing } \\
\text { Drying } \\
\text { Sawdust removal }\end{array}$ & Drying & \\
\hline $\begin{array}{l}\text { Manufacture of pulp, paper and } \\
\text { paper products }\end{array}$ & $\begin{array}{l}\text { Some pre-processors are } \\
\text { mainly building energy user }\end{array}$ & $\begin{array}{l}\text { Processes use a significant } \\
\text { amount of electricity: } \\
\text { Wood processing } \\
\text { Grindery } \\
\text { Pulp and paper machines } \\
\text { Drying } \\
\text { Pumping }\end{array}$ & $\begin{array}{l}\text { Drying } \\
\text { Water heating } \\
\text { Pulp production }\end{array}$ & Drying \\
\hline $\begin{array}{l}\text { Publishing, printing and } \\
\text { reproduction of recorded media }\end{array}$ & $\begin{array}{l}\text { Small plants are typical } \\
\text { building energy users }\end{array}$ & $\begin{array}{l}\text { Printing presses } \\
\text { Drying }\end{array}$ & Drying & Drying \\
\hline $\begin{array}{l}\text { Manufacture of chemicals and } \\
\text { chemical products }\end{array}$ & $\begin{array}{l}\text { Small plants are typical } \\
\text { building energy users }\end{array}$ & $\begin{array}{l}\text { Pumping } \\
\text { Fans } \\
\text { Negative and positive } \\
\text { Heating pressures } \\
\text { Cooling Drying }\end{array}$ & $\begin{array}{l}\text { Process heating } \\
\text { Drying }\end{array}$ & Drying \\
\hline $\begin{array}{l}\text { Manufacture of rubber and plastic } \\
\text { products }\end{array}$ & $\begin{array}{l}\text { Small plants are typical } \\
\text { building energy users }\end{array}$ & $\begin{array}{l}\text { Extruders and other melting } \\
\text { procedures } \\
\text { Process cooling especially in } \\
\text { the summer time }\end{array}$ & Process heating & \\
\hline $\begin{array}{l}\text { Manufacture of other non-metallic } \\
\text { mineral products }\end{array}$ & $\begin{array}{l}\text { Small plants are typical } \\
\text { building energy users }\end{array}$ & $\begin{array}{l}\text { Refiners } \\
\text { Grinders } \\
\text { Pumping } \\
\text { Thermal treatments } \\
\text { Melting processes }\end{array}$ & $\begin{array}{l}\text { Water heating } \\
\text { Thermal treatments }\end{array}$ & $\begin{array}{l}\text { Incineration } \\
\text { Melting } \\
\text { Thermal treatments }\end{array}$ \\
\hline Manufacture of basic metals & & $\begin{array}{l}\text { Processes use a significant } \\
\text { amount of electricity: } \\
\text { Melting } \\
\text { Thermal treatments }\end{array}$ & $\begin{array}{l}\text { Heating } \\
\text { Reactors }\end{array}$ & $\begin{array}{l}\text { Melting } \\
\text { Thermal treatments }\end{array}$ \\
\hline $\begin{array}{l}\text { Manufacture of fabricated metal } \\
\text { products, except machinery and } \\
\text { equipment }\end{array}$ & $\begin{array}{l}\text { Some plants are building } \\
\text { energy users }\end{array}$ & $\begin{array}{l}\text { Surface finishing } \\
\text { Thermal treatments } \\
\text { Processing and shaping } \\
\text { Welding }\end{array}$ & Drying & Thermal treatments \\
\hline $\begin{array}{l}\text { Manufacture of machinery and } \\
\text { equipment n.e.c. }\end{array}$ & $\begin{array}{l}\text { Some plants are building } \\
\text { energy users }\end{array}$ & $\begin{array}{l}\text { Shaping } \\
\text { Thermal treatments } \\
\text { Surface finishing } \\
\text { Welding }\end{array}$ & Drying & Thermal treatments \\
\hline $\begin{array}{l}\text { Manufacture of office machinery } \\
\text { and computers, electrical } \\
\text { machinery and apparatus n.e.c. }\end{array}$ & Typical building energy users & & & \\
\hline $\begin{array}{l}\text { Manufacture of radio, television } \\
\text { and communication equipment } \\
\text { and apparatus }\end{array}$ & Typical building energy users & & & \\
\hline $\begin{array}{l}\text { Manufacture of medical, precision } \\
\text { and optical instruments, watches } \\
\text { and clocks }\end{array}$ & & & & \\
\hline $\begin{array}{l}\text { Manufacture of motor vehicles, } \\
\text { trailers and semi-trailers, other } \\
\text { transport equipment }\end{array}$ & $\begin{array}{l}\text { Some plants are typical } \\
\text { building energy users }\end{array}$ & $\begin{array}{l}\text { Surface finishing } \\
\text { Welding }\end{array}$ & & Surface finishing \\
\hline $\begin{array}{l}\text { Manufacture of furniture, } \\
\text { manufacturing n.e.c. }\end{array}$ & $\begin{array}{l}\text { Some plants are typical } \\
\text { building energy users }\end{array}$ & $\begin{array}{l}\text { Drying } \\
\text { Surface finishing }\end{array}$ & & $\begin{array}{l}\text { Drying } \\
\text { Surface finishing }\end{array}$ \\
\hline
\end{tabular}


Table 2

Specific energy consumption of a number of industries expected on mixed industry parks $[111,112]$.

\begin{tabular}{|c|c|c|c|c|c|c|c|c|}
\hline Industry & $\begin{array}{l}\text { Specific } \\
\text { thermal energy } \\
\text { consumption }\end{array}$ & & & $\begin{array}{l}\text { Specific electrical } \\
\text { energy consumption }\end{array}$ & & & & \\
\hline Asphalt production sites & 0.28 & $\mathrm{GJ} / \mathrm{t}$ & 5400 & GJ/employee & 0.031 & $\mathrm{GJ} / \mathrm{t}$ & 600 & GJ/employee \\
\hline Laundries & & & 146.3 & GJ/employee & & & 41.3 & GJ/employee \\
\hline Surface treatment & & & 213.8 & GJ/employee & & & 159.3 & GJ/employee \\
\hline Rubber and synthetics processing & & & 62.3 & GJ/employee & & & 197.3 & GJ/employee \\
\hline \multirow{4}{*}{ Synthetics processing } & 0.18 & $\mathrm{GJ} / \mathrm{t}$ & & & & & & \\
\hline & 42,378 & GJ/premises & & & & & & \\
\hline & 55,769 & GJ/premises & & & & & & \\
\hline & 32,911 & GJ/premises & & & & & & \\
\hline \multirow[t]{3}{*}{ Rubber processing } & 6.3 & $\mathrm{GJ} / \mathrm{t}$ & & & & & & \\
\hline & 42,000 & GJ/premises & & & & & & \\
\hline & 41,463 & GJ/premises & & & & & & \\
\hline Textile production & & & 160 & GJ/employee & & & 160 & GJ/employee \\
\hline Carpet production & & & 283 & GJ/employee & & & 61.8 & GJ/employee \\
\hline Vegetable and fruit processing & 59,862 & GJ/premises & & & 47,034 & GJ/premises & & \\
\hline Cold stores & 0.02 & $\mathrm{GJ} / \mathrm{m}^{2}$ & & & 0.48 & $\mathrm{GJ} / \mathrm{m}^{2}$ & & \\
\hline Logistics & 1.45 & $\mathrm{GJ} / \mathrm{m}^{2}$ & & & 0.688 & $\mathrm{GJ} / \mathrm{m}^{2}$ & & \\
\hline Super market & & & 3.5 & GJ/employee & & & 84 & GJ/employee \\
\hline Super market $400-2500 \mathrm{~m}^{2}$ & 0.84 & $\mathrm{GJ} / \mathrm{m}^{2}$ & & & 2.292 & $\mathrm{GJ} / \mathrm{m}^{2}$ & & \\
\hline Super market $>2500 \mathrm{~m}^{2}$ & 0.39 & $\mathrm{GJ} / \mathrm{m}^{2}$ & & & 0.732 & $\mathrm{GJ} / \mathrm{m}^{2}$ & & \\
\hline Car sale & 0.53 & $\mathrm{GJ} / \mathrm{m}^{2}$ & & & 0.428 & $\mathrm{GJ} / \mathrm{m}^{2}$ & & \\
\hline Food and luxury food wholsesale & 1.71 & $\mathrm{GJ} / \mathrm{m}^{2}$ & & & 4.656 & $\mathrm{GJ} / \mathrm{m}^{2}$ & & \\
\hline Other wholesale & 0.89 & $\mathrm{GJ} / \mathrm{m}^{2}$ & & & 0.712 & $\mathrm{GJ} / \mathrm{m}^{2}$ & & \\
\hline Retail & 0.4 & $\mathrm{GJ} / \mathrm{m}^{2}$ & & & 1.024 & $\mathrm{GJ} / \mathrm{m}^{2}$ & & \\
\hline Retail $400-2500 \mathrm{~m}^{2}$ & 0.54 & $\mathrm{GJ} / \mathrm{m}^{2}$ & & & 0.5 & $\mathrm{GJ} / \mathrm{m}^{2}$ & & \\
\hline Retail $>2500 \mathrm{~m}^{2}$ & 0.33 & $\mathrm{GJ} / \mathrm{m}^{2}$ & & & 0.26 & $\mathrm{GJ} / \mathrm{m}^{2}$ & & \\
\hline Financial institutions & 1.14 & $\mathrm{GJ} / \mathrm{m}^{2}$ & & & 0.584 & $\mathrm{GJ} / \mathrm{m}^{2}$ & & \\
\hline Real-estate agents, corporate services & 0.68 & $\mathrm{GJ} / \mathrm{m}^{2}$ & & & 0.52 & $\mathrm{GJ} / \mathrm{m}^{2}$ & & \\
\hline Offices $200-500 \mathrm{~m}^{2}-20 \%$ best & & & & & 0.126 & $\mathrm{GJ} / \mathrm{m}^{2}$ & & \\
\hline Offices $200-500 \mathrm{~m}^{2}-50 \%$ best & & & & & 0.392 & $\mathrm{GJ} / \mathrm{m}^{2}$ & & \\
\hline Offices $200-500 \mathrm{~m}^{2}-80 \%$ best & & & & & 0.656 & $\mathrm{GJ} / \mathrm{m}^{2}$ & & \\
\hline Offices $500-1000 m^{2}-20 \%$ best & & & & & 0.115 & $\mathrm{GJ} / \mathrm{m}^{2}$ & & \\
\hline Offices $500-1000 m^{2}-50 \%$ best & & & & & 0.306 & $\mathrm{GJ} / \mathrm{m}^{2}$ & & \\
\hline Offices $500-1000 m^{2}-80 \%$ best & & & & & 0.497 & $\mathrm{GJ} / \mathrm{m}^{2}$ & & \\
\hline
\end{tabular}

energy service companies can join in into complex or demanding energy optimisation issues and deliver professional services or utilities.

For Lowe [66], concerning industrial symbiosis, the basic responsibility of a park developer and management is indeed to support companies in exploring the development of feasible exchanges and to help identify likely additional recruits who could be partners. "This has to be a self-organising process, with guidance and information from the recruiting and marketing team." Lowe [66] refers to the Danish Kalundborg industrial symbiosis example [93] for their personal interactions being vital to build the trust and business relationships. The basic 'ingredients' should be in place, namely the willingness of firms to actively cooperate and then the correct mix and structure of firms [79]. Instead of comprehensive planning, Desrochers [94] suggests that the priority of economic developers, in creating industrial symbiosis, should be the removal of its obstacles. The perspective of planning efforts in industrial symbiosis is rather one-dimensional, while businesses need to factor in many variables of their settlement and operation, such as manpower needs, proximity to markets, frequent face-toface interaction, capital availability and business climate. A small private firm would also concentrate on a much smaller set of waste products, and thereby explore more reuse possibilities and contact a larger number of potential customers [94].

Barriers for energy clustering should be removed to the maximum, or at least not be created during the development process of the industrial park, in the first place. However, before even considering energy integration of companies, there are barriers to energy efficiency within companies. They are mainly organisational and information related: lack of time or low priority; lack of resources as capital and (dedicated) personnel (therefore, lack of knowledge, expertise, also ill use of available information, instruments, training); an unconvincing case or short pay-back times requested [95]. A logical decision process from technically potential energy investments over a financial cost benefit analysis resulting in an investment decision is not confirmed empirically [96]. Diversity in energy efficiency and management under businesses from multiple sectors is explained by a big influence of corporate culture. The strategic value of energy efficiency is often low and electricity is regarded as readily available, and as out of control. Again a high end uncertainty adds to the retention.

In the case of SMEs, according to Waldmann and Keuc [95], "the target needs to be the people, not the technologies - right information to right people, right information at the right time, information given proactively - and the services, more than just kWhs - data, transformed to information and pushed to customer, information, transformed into market demand, activate service response (incl. financial institutions)". Cooremans' solution would be to make energy efficiency strategic, first making the energy consumption visible, then by identifying and highlighting the positive link between energy efficiency and core business [96].

Energy cooperation of neighbouring businesses is possible in energy exchange, distribution or in collective production (physical clustering); it can also entail a joint contracting of high-quality services, such as maintenance, energy monitoring, energy and by extension carbon management (service clustering). Yet, numerous possible barriers or feasibility factors on the cluster level (Table 3 ) determine the attainability of clustering and also the type of cluster. Depending on the specific approach for optimisation, different outputs are possible [97].

It looks like energy clustering is requiring a lot of time and expertise, even more than for internal energy efficiency optimisations. Therefore, investments for local energy production or integration (physical clustering) could also be outsourced to overcome 
Table 3

Feasibility factors of joint energy production and energy exchange.

\begin{tabular}{|c|c|c|}
\hline & Feasibility factors $[62,65,69,78,79,85,86,97,113]$ & Industrial park developers' influence? \\
\hline \multirow[t]{14}{*}{ Technical \& spatial } & $\begin{array}{l}\text { Fuel supply (in case of renewables: solar } \\
\text { irridiation, capacity factor, biomass, etc.) }\end{array}$ & $\begin{array}{l}\text { Location selection of park - urban } \\
\text { development plan }\end{array}$ \\
\hline & Connectivity of energy profiles, need for buffering & $\begin{array}{l}\text { Location policy of companies for possible } \\
\text { matching }\end{array}$ \\
\hline & Quality of energy flows & \\
\hline & Balance of different energy forms of energy (e.g. & \\
\hline & Need for backups & \\
\hline & Spatial and environmental preconditions & $\begin{array}{l}\text { Location selection of park - urban } \\
\text { development plan }\end{array}$ \\
\hline & Energy losses, exergy balance \& sustainability & \\
\hline & Potential for linking to the distribution network or & \\
\hline & a closed distribution system & \\
\hline & Technical reliability & \\
\hline & Flexibility in the energy production and & \\
\hline & consumption, growth/shrink scenario & \\
\hline & Technical complexity of installations and control & \\
\hline & Age and quality of the industrial park & Keep up quality, e.g. through park management \\
\hline \multirow[t]{13}{*}{ Financial } & $\begin{array}{l}\text { Capital accessibility and preconditions of } \\
\text { companies and third parties }\end{array}$ & \\
\hline & $\begin{array}{l}\text { Financial profitability for each partner (financial } \\
\text { return, risk remuneration) }\end{array}$ & \\
\hline & Pay-back period & Co-invest and accept higher payback period \\
\hline & $\begin{array}{l}\text { Balance of project costs and benefits over the } \\
\text { partners }\end{array}$ & \\
\hline & Unit price of self produced energy & \\
\hline & Overhead costs & \\
\hline & Flexibility in the energy production \& & \\
\hline & consumption, growth/shrink scenario & \\
\hline & Uncertainty about financial benefits \& & \\
\hline & expenditures & \\
\hline & Fluctuating energy prices & \\
\hline & Decline of the added value with increasing scale & \\
\hline & Influence on the market value of the companies & \\
\hline \multirow[t]{17}{*}{ Organisational } & Investing sufficient time in setup & $\begin{array}{l}\text { Facilitate communication - prepare possible } \\
\text { organisational setups }\end{array}$ \\
\hline & Communication between parties & Facilitate communication \\
\hline & Shared vision & Add company selection criteria \\
\hline & Reconciliation of the different interests & \\
\hline & $\begin{array}{l}\text { Synchronisation of investment and organisational } \\
\text { structures }\end{array}$ & \\
\hline & Contract period & \\
\hline & Lack of information about potential partners, & \\
\hline & company plans, energy consumption & \\
\hline & Flexibility in the energy production and & \\
\hline & consumption, growth/shrink scenario & \\
\hline & Influence on individual flexilibity & \\
\hline & Cluster decision making fluency & \\
\hline & Commitment and exit strategy & \\
\hline & Risk management & \\
\hline & Administrative load or release & \\
\hline & Administrative cooperation and cooperation of & \\
\hline & $\begin{array}{l}\text { Policy/interest of possible owner companies of } \\
\text { involved parties }\end{array}$ & \\
\hline \multirow[t]{4}{*}{ Legal } & $\begin{array}{l}\text { Permits (energy production, linking to distribution } \\
\text { net, environmental permits, spatial permits, safety } \\
\text { issues, etc.) }\end{array}$ & $\begin{array}{l}\text { Prepare energy installations in spatial } \\
\text { planning, prepare utilities for energy } \\
\text { installations in realisation }\end{array}$ \\
\hline & Distribution/definition of the responsibility, & \\
\hline & liability & \\
\hline & Potential of legal structuring of the cluster & \\
\hline \multirow[t]{10}{*}{ Social } & $\begin{array}{l}\text { Trust, openess, clarity between parties, reciprocal } \\
\text { relations }\end{array}$ & \\
\hline & Enthusiasm and experience of initiators and & \\
\hline & supportive actors or facilitators & \\
\hline & Perception about other feasability factors & \\
\hline & Mentality of cooperative thinking, live and let live & \\
\hline & Influence on companies' image & \\
\hline & Experience with interfirm clustering & Install park management and an \\
\hline & & inter-company deliberation platform \\
\hline & Win situation for stakeholders & \\
\hline & Politic \& social support (policy, NIMBY effects) & $\begin{array}{l}\text { Prepare for energy installations and carbon } \\
\text { reduction initiatives }\end{array}$ \\
\hline
\end{tabular}


these operational, technical, legal and financial barriers, bringing in so-called "energy service companies" (ESCO) for their expertise, capital, services, etc. Stanislaw [13] gives a promising view: "The new energy company will no longer profit from selling a commodity such as oil, gas, or electricity. Instead, it will be a high-value service company that provides light, heat and mobility, being rewarded for doing so in the most environmentally acceptable way."

Some energy companies are preparing themselves. Hence, e.g. Essent Local Energy Solutions provides an integrated "Trias Synergetica" service, "meeting local energy demand by using local energy sources and realising energy efficiency" [98]. Also Nuon is been shifting to services instead of pure utility delivery, as it provides a concept of industrial park management where Nuon "creates the most efficient and environmental friendly energy infrastructure, also searching for synergy benefits by cooperation between multiple companies" [99]. In the UK, Urban Splash and EcoCentreGen, and the Castle and Elephant Regeneration Team are preparing a multi-utility service company or MUSCO, which will provide a variety of utility services and can ensure strongly joined-up service infrastructure and a highly efficient customer interface [100,101]. "Low-Carbon municipal MUSCOs are an excellent opportunity for local authorities to grasp the full opportunity for sustainable service infrastructure in cities and towns, while ensuring the benefit for the community is fully realised" [100]. From ESCOs various types of guarantees can be demanded: supply; saving; function, operation and maintenance; quality and comfort [95]. Likewise, different types of management and legal structures can be developed, ranging from full outsourcing to special purpose vehicles (SPV).

\section{Case studies at mixed industrial parks in Flanders}

The physical structure and management of industrial parks should be compatible with, even invite, the long term structural changes needed to be competitive in a low-carbon economy and provide the utilities and space to do. To reduce the environmental impact of industry, industrial processes (and consumption) should be interlinked aiming for circulating material stocks and cascading energy. Material-based industrial symbiosis and industrial ecology should be strived for within a regional industrial metabolism, yet a sustainable energy strategy stresses local integration, in networks of companies and possibly surrounding energy sources and sinks, and integration within local renewable energy sources. The carbon footprint of the industrial park becomes a lead for designing, equipping, issuing and managing. In this section, different case studies illustrate further pilot projects initiated in Flanders to improve the energy-related carbon footprint of industrial parks. Three existing and one new industrial parks are discussed, which provide further input for defining an integral development and management concept for industrial parks aimed at energy sustainability.

\subsection{Carbon balance of an existing mixed industrial park Herdersbrug at Bruges}

A first example comprises the energy-related carbon footprint of an industrial park being evaluated, delivering important status information to the companies and the park management. It also clarifies that although this article is stressing on the energy efficiency management in the development of new industrial parks, the carbon balance of existing industrial parks is an even bigger issue in the transition to a low-carbon economy. Hence, an activated park management with a special focus on the carbon balance of the site, engaging the local businesses and possibly energy service companies are invited to maximise the renewable energy production potential and to grasp energy efficiency upgrades maximally.
The 228 ha industrial park of Herdersbrug comprises 92 SMEs, a municipal waste-to energy incinerator with a district heating network, fourteen $600 \mathrm{~kW}$ and seven $1.8 \mathrm{MW}$ wind turbines and a combined cycle gas turbine power plant on its site. A parkwide inventory was made of the $\mathrm{CO}_{2}$ emissions corresponding to energy (electricity and fossil fuel) consumption (excluding the power plant) and waste incineration in 2007, and of the existing renewable energy generation [102]. It was found that Herdersbrug industrial park is "carbon neutral", in the sense that enough renewable energy is produced to cover the electricity consumption on the site (accounting for $21 \mathrm{kton} \mathrm{CO}_{2}$ ). However, from the $\mathrm{CO}_{2}$ released as a consequence of fossil fuel consumption and waste incineration, only a small fraction is neutralised by existing and projected renewable energy production, even in the case of massive investments in photovoltaic solar power for every roof on the park, added by a biomass fermentation and biogas-to energy CHP with district heating, a more performant turbine at the waste incineration, and the replacement of the existing $600 \mathrm{~kW}$ wind turbines by a smaller number of $2 \mathrm{MW}$ turbines. From the total $\mathrm{CO}_{2}$ emission (262 kton) in 2007 , only 93 kton or $35 \%$ can be neutralised by existing and the projected renewable energy generation on the park. Of course, energy efficiency measures within companies were not analysed at this moment, but these figures illustrate the massive challenge the businesses and park management are looking at.

\subsection{Collective energy production on a new mixed industrial park Sappenleen at Poperinge}

Joint electricity production can be managed in a very flexible way, while multiple stakeholders can participate and ESCOs can be contracted for services as well as expertise.

Next to the still rather passive approach of informing, stimulating and enforcing companies to lift up their energy efficiency and deploy renewables, as applied on Kazerne Lissewege, the West Flanders Intermunicipal Association also searched for an operational model in which it could start up mid scale energy production sites, invite a private energy company in the development and exploitation of the installations, and invite the settling 'carbon neutral firms' to join in to invest as partners and owners of the installations, during the issuing process on an industrial park. The driving forces behind are

- urban development expectations on eco-industrial parks which do not allow a morbid growth of all kinds of renewable energy installations with spatial impact;

- industrial parks being of the most acceptable places to install large scale wind turbines in Flanders;

- high financial profitability of mid scale installations;

- increase of the amount of renewable power that could be produced on an industrial park;

- creation of the possibility for all companies on the industrial park to step in and not just a few who are fortunate to have the selected lot to install energy installations, as the urban impact can also effect all companies;

- support to large energy users which cannot produce sufficient energy on their site;

- support to small industrial parks which are not able to produce sufficient energy locally;

- keep a share of the investment capital and correspondent the financial profit to finance the carbon neutrality services to the businesses.

Together with wvi, Deloitte and Laga, we have worked out a legal structure, tailored to the EU, national and regional legal context, which can hold multiple different and independent energy producing partnerships to fit local circumstances and stakeholders 
interests and concerns. A first application will install three wind turbines on an existing industrial park, Sappenleen, which will be enlarged from around 80 to 110 ha. In this project there's no hard link between the energy consumption of a company and its share of energy production: the share or loan of a company in or to the production partnership creates the right to a share of the profit of the project to compensate expenditures on electricity costs, while for the produced energy the best ratio of financial return, stability and security, and operational and administrative load will be searched by the shareholders' meeting. The partnership will engage a cooperation with an energy supplier only to take in the produced energy, or possibly to deliver the produced energy to the companies too and therefore act as the energy balancing servicer. A proper exit strategy for companies will be worked out as well.

\subsection{Energy clustering on an existing mixed industrial park Ieperleekanaal at Ieper}

Another existing 250 ha mixed industrial park is now being evaluated, this time focusing on potential energy exchanges. The park indeed shows potential for energy integration, for heat and electricity. Moreover, existing parks may already incorporate virtual batteries to store energy. By managing local energy sources, consumers and batteries, the autonomy of the park can be strived for.

The site contains numerous SMEs, a number of biomass gasification installations and thermal green electricity production units, a cogeneration plant and several steam ovens compatible to switch to biogas, several wood processors, seven $2 \mathrm{MW}$ wind turbines, and a cold store. In the neighbourhood an existing hospital and a new housing development are potential partners as well. Companies were invited to take part in a free study financed by wvi, the park developer and manager, and the Provincial Development Agency of West Flanders. After a thorough inventory, a number of potential clusters came up, which are now being analysed in detail:

- a warm water link between a producer of household and personal care products and a hospital near the park, passing multiple smaller interested enterprises;

- a warm water link between a dye-works firm and a distributor of cooling and freezing installations and heat pumps;

- a new biomass boiler for a food producer and a waste processor;

- a private electricity line between a biomass-electricity producer, a plastic products producer and a cold store.

Cold stores are an interesting component. They can be managed as virtual batteries, to flatten the grid load curve of consumers or uncontrollable generation, e.g. random generated wind energy [103]. This way less fossil fuel fired energy plants need to run in standby mode, still causing GHG emissions and partly compensating the GHG reduction benefit of renewable energy. Demand management also increases the chances for raising the renewable energy share of our total energy production. When this flattening can be arranged locally instead at a regional market level, more energy can be saved as losses over the grid can be evaded. This reflects back to the note on microgrids and shows storage capacity already being available at industrial parks. Demand management in premises and processes can create additional virtual storage capacity.

\subsection{Design of a new local mixed industrial park Posterijlaan at Pittem}

As a last case study, new industrial parks show an important informational barrier in the design process. Specialised space and utilities are recommended, yet the target is still unknown and companies and energy profiles may show large variability in the

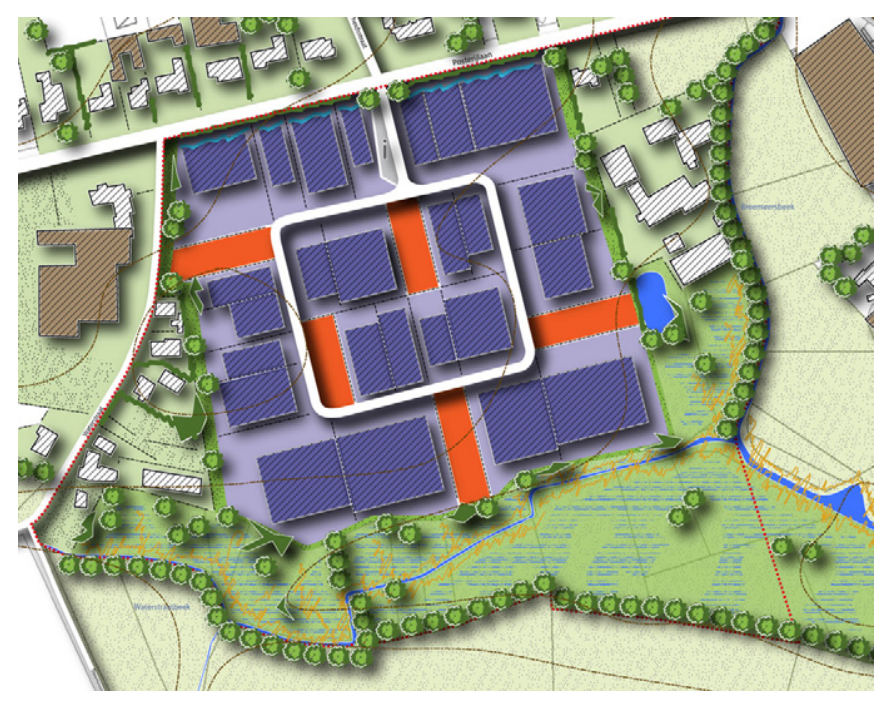

Fig. 2. Urban structure of local industrial park Posterijlaan.

operational phase of the park. Instead, spatial flexibility can incorporate energy flexibility.

The wvi received the assignment to develop a new 5 ha "carbon neutral" local mixed industrial park at Pittem in West Flanders. At the time of design, the park will hold an uncertain amount of small local companies, yet the design of the park cannot wait for all settling firms to be known. The activities of the companies which are known at that time are listed in Table 4a. Aro's energy characteristics are also recalled, which delivers a first impression of the energy consumption that these companies bring along.

Local industrial parks rarely house heavy industry, so from the perspective of traditional industry most companies will be denoted as building energy users. A typical office in Flanders has a yearly heat consumption of around $200 \mathrm{kWh} / \mathrm{m}^{2}$ or $0.72 \mathrm{GJ} / \mathrm{m}^{2}$. This is deducted from the maximum allowable heat consumption of known built industry buildings with built-in offices, with the software for the official registration of the energy performance of buildings [104]. According to Table 2, a typical value for the electricity consumption of offices is around $100 \mathrm{kWh} / \mathrm{m}^{2}$ or $0.36 \mathrm{GJ} / \mathrm{m}^{2}$. These figures are used in an energy consumption assessment, together with known statistics, based on the activity and lot area companies request (Table $4 \mathrm{~b}$ ).

From this exercise, it can be seen that very little information is known to estimate the energy consumption at the site. Requested lot areas are not always given, yet if they have, practice shows they usually are overestimated. Together with the assumption on energy consumption, it looks more like gambling than estimating. At this stage, only 7 candidates are known out of 20-30 possible firms that will settle eventually. Even if the energy data related to these 7 companies were precisely known, then clearly still a lot of variation in the energy consumption can arise for the total: in the previous table the energy consumption varies from 125 to $1700 \mathrm{GJ}$ for heat and from 230 to $4650 \mathrm{GJ}$ for electricity. It is clear that no heating production system or connecting network can be designed at this moment. Electricity on the other hand is a lot more flexible because of the grid connection. A local smart grid is always interesting.

However, while the park is actually designed for maximum spatial sustainability, a number of measures also increase to the energy efficiency and flexibility (Fig. 2):

- Businesses' buildings will be grouped 2 by 2, even more where possible, to increase the density, which decreases the energy loss wall surface. 
Table 4a

Analysing the energy use of candidate companies for Posterijlaan (the authors' extra comments in italic).

\begin{tabular}{|c|c|c|c|c|c|}
\hline Interested company's activity & Industry & $\begin{array}{l}\text { Significant building } \\
\text { energy user }\end{array}$ & $\begin{array}{l}\text { Significant process } \\
\text { electricity } \\
\text { consumption }\end{array}$ & $\begin{array}{l}\text { Significant process } \\
\text { heat consumption } \\
\text { (water, steam, hot oil) }\end{array}$ & $\begin{array}{l}\text { Significant process } \\
\text { heat combustion user } \\
\text { (oil, natural gas and } \\
\text { solid fuels) }\end{array}$ \\
\hline $\begin{array}{l}\text { Wood import and } \\
\text { manufacturing of wooden } \\
\text { playgrounds }\end{array}$ & $\begin{array}{l}\text { Manufacture of wood and } \\
\text { of products of wood and } \\
\text { cork, except furniture; } \\
\text { manufacture of articles of } \\
\text { straw and plaiting matter }\end{array}$ & $\begin{array}{l}\text { Typical building energy } \\
\text { users } \\
\text { Not all of the buildings } \\
\text { are heated }\end{array}$ & $\begin{array}{l}\text { Wood processing } \\
\text { Drying } \\
\text { Sawdust removal }\end{array}$ & Drying & \\
\hline $\begin{array}{l}\text { Vulcanising rubber and PVC, } \\
\text { rubber coating }\end{array}$ & $\begin{array}{l}\text { Manufacture of rubber and } \\
\text { plastic products }\end{array}$ & $\begin{array}{l}\text { Small plants are typical } \\
\text { building energy users }\end{array}$ & $\begin{array}{l}\text { Extruders and other } \\
\text { melting procedures } \\
\text { Process cooling } \\
\text { especially in the } \\
\text { summer time }\end{array}$ & Process heating & \\
\hline Manufacturing of moulds & $\begin{array}{l}\text { Manufacture of machinery } \\
\text { and equipment n.e.c. }\end{array}$ & $\begin{array}{l}\text { Some plants are } \\
\text { building energy users }\end{array}$ & $\begin{array}{l}\text { Shaping } \\
\text { Thermal treatments } \\
\text { Surface finishing } \\
\text { Welding }\end{array}$ & Drying & Thermal treatments \\
\hline Carwash and tire centre & Retail & & & & \\
\hline $\begin{array}{l}\text { Retail and distribution of } \\
\text { sports equipment }\end{array}$ & Retail and logistics & & & & \\
\hline Transport and storage & Logistics & & & & \\
\hline $\begin{array}{l}\text { Distribution of agricultural } \\
\text { products }\end{array}$ & Retail, wholesale & & & & \\
\hline
\end{tabular}

- Five lots will be reserved at least till the end of the issuing process and could function as lots for installing collective functions if businesses see an opportunity. One of those functions could be a small to mid scale central energy plant for a cluster of companies. Therefore however, heat consuming and producing firms should be clustered for optimal spatial proximity.

- A number of lots can be joined together to develop a multi tenant building. This building can be designed for the passive standard and introduce collective heating, ventilation and possible cooling systems.

In addition the energy efficiency standards and requirement for carbon neutrality for electricity and possibly heating will be applied. Clearly it is still interesting to request the estimated energy consumption figures from the companies before issuing the lots. If a lot of waste heat would arise, then those companies can be redirected to other industrial parks or matching companies could be searched to locate on this park. First however, process improvements or even radically changing processes could resolve the problem internally.

\section{Results and discussion}

The legally binding "carbon neutrality" initiative for industrial park developers and managers in Flanders has initiated first steps in an issuing process of industrial land, taking along the carbon footprint of companies. Businesses interested for location as well as building firms react positively on the extensive support from park developer and management, and accept the additional energy conditions, which direct them towards the future energy and building landscapes. Certainly, the 'carbon neutrality' conditions activate attention to the topic, of businesses as well as within the integral team of the industrial park developer and management.

This extended park management has now to be embedded into a physical structure and issuing process that stimulates energy clustering or at least reduces the barriers to clustering. As premises and

Table 4b

Analysing the energy use of candidate companies for Posterijlaan (the authors' assumptions in italic).

\begin{tabular}{|c|c|c|c|c|c|}
\hline $\begin{array}{l}\text { Interested company's } \\
\text { activity }\end{array}$ & $\begin{array}{l}\text { Requested lot area } \\
\left(\mathrm{m}^{2}\right) \text { (heated floor } \\
\text { surface) }\end{array}$ & $\begin{array}{l}\text { Specific heat } \\
\text { consumption per } \\
\text { year (office energy } \\
\text { use as estimate) }\end{array}$ & $\begin{array}{l}\text { Rough estimate } \\
\text { of heat } \\
\text { consumption } \\
\text { per year }(\mathrm{GJ})\end{array}$ & $\begin{array}{l}\text { Specific electricity } \\
\text { consumption per } \\
\text { year (office energy } \\
\text { use as estimate) }\end{array}$ & $\begin{array}{l}\text { Rough estimate } \\
\text { of electricity } \\
\text { consumption } \\
\text { per year (GJ) }\end{array}$ \\
\hline $\begin{array}{l}\text { Wood import and } \\
\text { manufacturing of } \\
\text { wooden playgrounds }\end{array}$ & $3500(1000)$ & $0.72 \mathrm{GJ} / \mathrm{m}^{2}$ & $720 \mathrm{GJ}$ & $0.36 \mathrm{GJ} / \mathrm{m}^{2}$ & $360 \mathrm{GJ}$ \\
\hline $\begin{array}{l}\text { Vulcanising rubber and } \\
\text { PVC, rubber coating }\end{array}$ & (not given) & 62.3 GJ/employee & $125 \mathrm{GJ}$ & 197.3 GJ/employee & $400 \mathrm{GJ}$ \\
\hline $\begin{array}{l}\text { Manufacturing of } \\
\text { moulds }\end{array}$ & $\begin{array}{l}\text { (not given) } \\
2000(1000)\end{array}$ & $0,72 \mathrm{GJ} / \mathrm{m}^{2}$ & $720 \mathrm{GJ}$ & $0,36 \mathrm{GJ} / \mathrm{m}^{2}$ & $360 \mathrm{GJ}$ \\
\hline $\begin{array}{l}\text { Carwash and tire } \\
\text { centre }\end{array}$ & 2000 & & $720 \mathrm{GJ}$ & & $360 \mathrm{GJ}$ \\
\hline $\begin{array}{r}\text { Retail and distribution } \\
\text { of sports equipment }\end{array}$ & $1000(500)$ & $0.54 \mathrm{GJ} / \mathrm{m}^{2}$ & $250 \mathrm{GJ}$ & $0.5 \mathrm{GJ} / \mathrm{m}^{2}$ & $230 \mathrm{GJ}$ \\
\hline Transport and storage & $1000(500)$ & $1.45 \mathrm{GJ} / \mathrm{m}^{2}$ & $750 \mathrm{GJ}$ & $0.688 \mathrm{GJ} / \mathrm{m} 2$ & $350 \mathrm{GJ}$ \\
\hline $\begin{array}{l}\text { Distribution of } \\
\text { agricultural products }\end{array}$ & (not given) (1000) & $1.71 \mathrm{GJ} / \mathrm{m}^{2}$ & $1700 \mathrm{GJ}$ & $4.656 \mathrm{GJ} / \mathrm{m} 2$ & $4650 \mathrm{GJ}$ \\
\hline
\end{tabular}


Table 5

Key aspects in developing energy-related low-carbon industrial parks.

\begin{tabular}{|c|c|c|c|c|c|}
\hline $\begin{array}{l}\text { Park focus and location } \\
\text { selection, and preparation }\end{array}$ & $\begin{array}{l}\text { Spatial and urban park } \\
\text { design }\end{array}$ & Realisation of park & $\begin{array}{l}\text { Issuing available business } \\
\text { space to companies }\end{array}$ & Exploitation and management & Enforcement \\
\hline \multirow{6}{*}{$\begin{array}{c}\text { Check local energy autonomy } \\
\text { potential on renewables }\end{array}$} & $\begin{array}{l}\text { Prepare distribution } \\
\text { system for renewable } \\
\text { energy production and } \\
\text { possible energy } \\
\text { integration }\end{array}$ & $\begin{array}{l}\text { Install intelligent } \\
\text { distribution system }\end{array}$ & $\begin{array}{l}\text { Activate inter-company } \\
\text { deliberation }\end{array}$ & Activate park management & \multirow{6}{*}{$\begin{array}{l}\text { Performance } \\
\text { prerequisites }\end{array}$} \\
\hline & $\begin{array}{l}\text { Allow passive buildings } \\
\text { to be build }\end{array}$ & $\begin{array}{l}\text { Possibly build passive } \\
\text { buildings to sell or rent }\end{array}$ & $\begin{array}{l}\text { Support SMEs in design of } \\
\text { buildings and installations }\end{array}$ & & \\
\hline & & & Performance prerequisites & $\begin{array}{l}\text { Energy and carbon footprint } \\
\text { monitoring }\end{array}$ & \\
\hline & $\begin{array}{l}\text { Maximise local energy } \\
\text { production and } \\
\text { integration } \\
\text { potential/erase } \\
\text { spatial/urban barriers }\end{array}$ & $\begin{array}{l}\text { Possibly install local } \\
\text { energy installations }\end{array}$ & $\begin{array}{l}\text { Energy profile based matching } \\
\& \text { co-siting of companies to } \\
\text { raise potential of clustering }\end{array}$ & $\begin{array}{l}\text { Detect potential, stimulate and } \\
\text { facilitate energy production, } \\
\text { integration and raising energy } \\
\text { efficiency }\end{array}$ & \\
\hline & & & $\begin{array}{l}\text { Missing complementary } \\
\text { energy profiles? }\end{array}$ & $\begin{array}{l}\text { Missing complementary } \\
\text { energy profiles? }\end{array}$ & \\
\hline & $\begin{array}{l}\text { Interest of ESCOs for } \\
\text { cooperation? }\end{array}$ & $\begin{array}{l}\text { Interest of ESCOs for } \\
\text { cooperation? }\end{array}$ & $\begin{array}{l}\text { Interest of ESCOs for } \\
\text { cooperation? }\end{array}$ & $\begin{array}{l}\text { Interest of ESCOs for } \\
\text { cooperation? }\end{array}$ & \\
\hline
\end{tabular}

internal process optimisation is not considered sufficient to limit greenhouse emissions in Flanders, structural transition is called for, aiming for industrial clustering and energy autonomy based on renewables. A sustainable energy strategy stresses a Trias Energetica approach and local integration, in networks of companies and possibly surrounding energy sources and sinks, and within local renewable energy sources. The existence of an industrial park entity can produce an essential added value concerning the energy or carbon profile of the companies located at the park, if the physical framework is compatible with, even invites, the long term structural changes needed to be competitive in a low-carbon economy. Energy-intensive businesses as well as non energy-intensive businesses can be clustered into thematic energy projects. However, utilities stimulating energy clustering play a key role, which have to fine-tuned to the target group. To intensify energy clustering on industrial parks, the following strategies are available:

- Companies having opportunities for traditional energy exchange (and by extension material and water exchange) can be regrouped. Upon internal capacity, process and energy efficiency optimisation, residual energy (heat, electricity, steam, cold, biogas, etc.) can be delivered to other companies. Vice versa, a company can search for residual energy sources of neighbouring firms and use or upgrade them.

- Offices or warehouses can be designed for minimal energy consumption, and can be built in horizontal and vertical strings. Here, collective heating, ventilation and cooling installations or shared utilities can be implemented, such as a collective reception, printing, storage, etc.

- In both cases, collective production of energy could be profitable, using local renewable energy sources. A large scale production unit is an option, as well as combining multiple smaller scaled units, identical or diversified but complementary, all supported by a microgrid.

The carbon footprint of the industrial park becomes a lead for designing, equipping, issuing and managing. However, a personal and frequent communication of the park developer and manager is needed in the first place to convince businesses to locate on its park, and second to support, facilitate and stimulate companies to reach for low-carbon building and operation. SMEs may strongly need the energy expertise of the park developer or manager. The latter also keeps a helicopter view, yet is closely associated to identify clustering opportunities together with the located businesses and possible external connections. Additionally, specialised energy service companies can join in into complex or demanding energy optimisation issues and deliver professional services or utilities.

Therefore, the development of an energy-related low-carbon industrial park begins in the earliest phase of development and continues to demand attention during the whole life-time of the park. Matching these key aspects to the development till exploitation process of an industrial park, holding the park focus and location selection and preparation phase, the conception or design phase, the realisation phase, the issuing phase, and the exploitation and enforcement phases [105], energy management on industrial parks could be structured as in Table 5 .

The case studies point out that energy management can and should be introduced on new and existing industrial parks. Existing sites, as Ieperleekanaal and Herdersbrug, show a high potential for reducing the energy-related carbon footprint, and the value of a site-oriented inventory and attainability study by park management, local authorities or ESCOs to maximise the existing potential. Sappenleen, Ieperleekanaal and Herdersbrug all show potential for energy clustering as well, for heat and electricity. On existing parks, companies are known and energy consumption can easily be metered or estimated, however the spatial setting is fixed. An enforcement method as on the new Flemish "carbon neutral" parks to activate attention and interest for energy efficiency is missing, although increasing driving forces for climate action may lift up interest after all. However, the case of Herdersbrug also leads to the conclusion that real (energy-related) carbon neutrality, including all energy sources, can be a much more challenging task than the carbon neutrality defined by the Flemish government. Even then, the carbon footprint actually extends to multiple other sources as processes and transport, emissions embedded in infrastructures, machinery, raw materials, products, etc. -, other global warming emissions than $\mathrm{CO}_{2}$ - as described in Section 2.2 - and across full value chains. Therefore, carbon footprint calculation and optimisation of entire premises, organisations and value chains should still be encouraged. Yet, strong carbon footprint prerequisites best play a role at higher levels than an industrial park, if the park entity itself cannot produce an added value.

For new developments, certainly for mixed industrial parks, the adaptation of the physical structure and energy utilities to the business processes expected on the site is difficult. Companies are not always known on beforehand, nor the business sectors and its related expected floor space. Useful energy consumption data are therefore difficult to gather. If the floor space of offices and possibly housing is known, the energy consumption for heating and electricity can be estimated. Yet, it is not always certain whether 
Table 6

Barriers to integrating energy clustering in development of industrial parks.

\begin{tabular}{|c|c|c|}
\hline & Possible barriers & Industrial park developers' influence? \\
\hline Technical \& spatial & $\begin{array}{l}\text { - Failing supply of renewable fuel (solar irridiation, capacity factor, } \\
\text { biomass, etc.) } \\
\text { - Hindering spatial and environmental preconditions } \\
\text { - No potential for capturing and using useful heat losses } \\
\text { - Heat consumption to low for deploying CHP, renewable fuel or heat } \\
\text { pumps fueled on high-temperature heat } \\
\text { - Lack of matching energy profiles } \\
\text { - High flexibility in the energy production and consumption on site }\end{array}$ & $\begin{array}{l}\text { - Adequate location selection and urban design } \\
\text { - Calculate and define an energy capacity of the site (or } \\
\text { for different design scenarios) } \\
\text { - Location policy for heat consumers } \\
\text { - Define and reserve adequate space in parks or } \\
\text { subzones of parks for clustering heat consumers } \\
\text { - Maximise flexibility with smart utilities } \\
\text { - Stimulate decreasing process temperatures } \\
\text { - Stimulate use of electricity driven heat pumps for } \\
\text { low temperature heat and fueled by renewable energy }\end{array}$ \\
\hline Financial & $\begin{array}{l}\text { - Capital accessibility \& preconditions of companies \& third parties } \\
\text { - Financial profitability for each partner (financial return, risk } \\
\text { remuneration) } \\
\text { - Pay-back period } \\
\text { - Balance of project costs and benefits over the partners } \\
\text { - Unit price of self produced energy } \\
\text { - Overhead costs } \\
\text { - Uncertainty about financial benefits \& expenditures }\end{array}$ & - Look for co-investors, partnerships with ESCOs \\
\hline Organisational & $\begin{array}{l}\text { - Increasing time in development of industrial parks } \\
\text { - Lack of information about potential companies, energy consumption } \\
\text { - Variability in time on settled companies \& energy consumption } \\
\text { - Low interest and engagement of enterprises }\end{array}$ & $\begin{array}{l}\text { - Build in energy efficiency and energy autonomy } \\
\text { requisites in the industrial park criteria } \\
\text { - Gain experience within personnel on all levels } \\
\text { - Build in flexible yet solid design } \\
\text { - Allow physical interfirm connections to be installed } \\
\text { during the total lifetime of the park } \\
\text { - Set basic energy and carbon performance conditions } \\
\text { - Add selection criteria } \\
\text { - Request design of buildings and installations prior to } \\
\text { selling the lot }\end{array}$ \\
\hline Legal & $\begin{array}{l}\text { - Permits (energy production, linking to distribution net, } \\
\text { environmental permits, spatial permits, safety issues, etc.) }\end{array}$ & $\begin{array}{l}\text { - Prepare energy installations in spatial planning, } \\
\text { prepare utilities for energy installations in realisation }\end{array}$ \\
\hline Social & $\begin{array}{l}\text { - Trust, openess, clarity between parties, reciprocal relations } \\
\text { - Enthusiasm and experience of initiators and supportive actors or } \\
\text { facilitators } \\
\text { - Perception about other feasability factors } \\
\text { - Mentality of cooperative thinking, live and let live } \\
\text { - Influence companies' image } \\
\text { - Experience with interfirm clustering } \\
\text { - Politic \& social support (policy, NIMBY effects) }\end{array}$ & $\begin{array}{l}\text { - Express the need and opportunities of low-carbon } \\
\text { operation } \\
\text { - Prepare for energy installations and carbon reduction } \\
\text { initiatives }\end{array}$ \\
\hline
\end{tabular}

companies will need office space and which floor space, moreover it can be variable in time. The energy consumption of warehouses is even more complex. Companies can install just some storage, or can have electricity or heat consuming processes. If the interested companies are known during the design or issuing process of the industrial park, it is best to work with energy data related to their processes. If a certain sector wants to be attracted in a region, energy consumption data of the companies should be added to their location preferences. However, strong variability over time in energy consumption adds to the complexity for specialised and capital-intensive energy utilities. A more flexible energy form, such as electricity, could be stimulated. Local energy excesses and deficiencies are compensated through the distribution network. Joint electricity production can be managed in a very flexible way, while multiple stakeholders can participate and ESCOs can be contracted for services as well as expertise. Electricity driven heat pumps can be used for heating when heating temperatures as low as $50-60^{\circ} \mathrm{C}$, are required. Where electrification is not possible however, energy generated by heat may still have to be used: biomass, combined heat power installations or heat pumps fueled with biomass or gas combustion.

Another strategy to tackle new low-carbon industrial parks can be a spatial approach. In urban planning and architecture, a strong formal structure can create a meaning, and preserves its functioning and quality whatever the momentary function and styling could and will be. Spatial flexibility yet solidity to buildings and urban design can be added through a design that focuses on the timeless elements, which will be the carrier of the momentary. The timeless elements will have to be able to give life to various types of momentary activities, of which only a limited idea can be formed about. Therefore, form cannot follow function but allocation needs to be directed by form [106-108]. Also, innovative forms can be created when use is thought of activities rather than functions of types of spaces [109]. Reflecting back to the energy infrastructure, the following concepts could be researched further:

- The physical infrastructure could be designed to allow physical interlinking of companies at any time when needed by reserving corridors of land, in buildings, in the air, supported by technical and architectural guidelines for an urbanistic acceptable or strengthening insertion. As an example, the project of Posterijlaan creates its flexibility in the reservation of (strategically placed) voids, which can be used for cooperative (energy) projects sometime during the exploitation of the park. This strategy cannot replace an issuing procedure and park management to physically colocate and stimulate integration of matching energy profiles of companies, yet adds to the industrial park's capability to allow physical clustering.

- Also more specific energy zones in an industrial park could be defined, originating from potential on-site energy production, and therefore a range of total energy consumption to be strived for within the cluster. Companies are then allowed in that cluster 
only if their energy profile fits in the remainder energy capacity of the zone, or can use waste heat of other companies. Especially year round heat users and high temperatures heat users are a specific type of businesses that could each be joined to install efficient collective heat production (or CHP) at the matching temperature and possibly be interlinked to each other. Indeed, allocation directed by form, and infrastructure. Additionally, for non-intensive heat users (low heat consumption, seasonal), district heating systems can be too expensive, unless these heat users can be linked to a financially viable district heating system without considerable surplus costs.

- To increase tailoring even further, different activities of firms could be separated and joined with similar or matching activities of other companies. Specialised building types for one or multiple matching activities can then be scheduled to maximise efficiency and effectiveness: passive offices, warehouses for working personnel, warehouses for storage and logistics, restaurants, fitness, cooling cells, etc. A company takes a piece of each building as it desires; a processes or activities park is created rather than a companies park, an industrial park rather than an industries park, a business park rather than a businesses park [110].

For a nonexhaustive overview of possible barriers, see Table 6 . Potential measures by industrial park developers are also shown.

\section{Conclusion}

The Flemish carbon neutrality initiative on new industrial parks is a prime step, building towards more energy efficient buildings and processes, and acting as a stimulus for the production and consumption of green electricity. It should entail further bottom-up investments that support the low-carbon economy and serve as an example for energy management activation on existing parks too. However, not only the park management structure but the industrial parks itself as well, as the physical and operational framework, should be prepared to invite, stimulate, facilitate and possibly enforce low-carbon operation. The design of industrial parks is focused on energy efficient buildings, renewable energy production and energy integration. Cooperation is initiated and intensified by clustering buildings and processes, by energy exchange, collective production and joint contracting of energy services. In this process, it is crucial to detect the companies having opportunities to cluster and to position them in close neighbourhood, to install adapted utilities for distributed energy production and energy exchange, and to clear up the maximum of barriers to clustering. For business parks that operate in unity stand more chances for energy autonomy based on local renewable energy sources. Yet, practice shows uncertainty and variability in time can keep developers from tailoring industrial park design and energy production and distribution systems to the needs of settling enterprises. Instead solidity and flexibility of industrial parks could be gained, and the offer of business space could be diversified, supported by a persevering issuing procedure, to join similar and matching energy profiles. Attention must not only be paid to companies consuming or generating renewable electricity; also intensive heat users and producers must play a strategic role. Listing supply and demand of hot and cold streams and screening heat consumption of companies, can create opportunities for waste heat exchange, and renewable heat generation and use. Further research is needed on flexible designing and thermal planning of mixed industrial parks.

\section{Acknowledgements}

Thankfulness and gratitude is expressed to the West Flanders Intermunicipal Association commissioning the Ghent University research group Environmental and Spatial Management to investigate the carbon neutrality options in site development and park management and support the onsite testing of new practices.

\section{References}

[1] Allison I, Bindoff NL, Bindschadler RA, Cox PM, de Noblet N, England MH, et al. The Copenhagen diagnosis. Sidney: The University of New South Wales Climate Change Research Centre (CCRC); 2009. p. 60.

[2] IPCC. Climate Change 2007: Synthesis Report. Valencia; 2007.

[3] Welzer H Klimakriege. Wofür im 21. Jahrhundert getötet wird. Frankfurt am Main: S. Fischer; 2008.

[4] Smith JB, Schneider SH, Oppenheimer M, Yohe GW, Hare W, Mastrandrea MD, et al. Assessing dangerous climate change through an update of the Intergovernmental Panel on Climate Change (IPCC) "reasons for concern". PNAS 2008.

[5] Stern N, Peters S, Bakhshi V, Bowen A, Cameron C, Catovsky S, et al. The Stern review: the economic of climate change. London: HM Treasury; 2006.

[6] Flemish Environment Agency. State of the Environment Report; 2010. http://www.milieurapport.be/ August 10th 2010.

[7] Le Quéré C, Raupach MR, Canadell JG. G. M. Trends in the sources and sinks of carbon dioxide. Nature Geoscience 2009.

[8] Metz B, Davidson OR, Bosch PR, Dave R, Meyer LA. Contribution of Working Group III to the Fourth Assessment Report of the Intergovernmental Panel on Climate Change; 2007.

[9] Köne AC, Büke T. Forecasting of $\mathrm{CO}_{2}$ emissions from fuel combustion using trend analysis. Renewable and Sustainable Energy Reviews 2010;14:2906-15.

[10] Carpentier N. Zin en onzin van de 'heilige' tweegradengrens. De Morgen; 2009.

[11] Carbon Constraint Initiatives; 2010. http://www.carbon-constraintinitiatives.com/ March 9th 2010.

[12] Carbon Disclosure Project; 2010. http://www.cdproject.net/ March 9th 2010.

[13] Stanislaw JA. Climate changes everything: the dawn of the green economy. Deloitte 2008.

[14] CO2Logic; 2010. http://www.co2logic.com/ March 9th 2010.

[15] Climate Neutral Group; 2010. http://www.climateneutralgroup.com/ March 9th 2010.

[16] The Climate Group; 2010. http://www.theclimategroup.org/ March 9th 2010.

[17] The Carbon Trust; 2010. http://www.carbontrust.co.uk/ March 9th 2010.

[18] Grobbel C, Maly j, Molitor M. Preparing for a low-carbon future. The McKinsey Quarterly 2004.

[19] Tibbs H. Industrial ecology. An environmental agenda for industry. Emeryville, CA: Global Business Network; 1993.

[20] Enkvist P-A, Nauclér T, Oppenheim JM. Business strategies for climate change. The McKinsey Quarterly 2008;2008:24-33.

[21] The Goldman Sachs Group. Change is coming: A framework for climate change - a defining issue of the 21st century; 2009.

[22] Ernst \& Young. The 2009 Ernst \& Young business risk report. The top 10 risks for global business; 2009.

[23] A.T. Kearney Management Consultants. "Green” Winners. The performance of sustainability-focused companies during the financial crisis; 2009.

[24] Bonini S, Oppenheim JM. The next environmental issue for business. The McKinsey Quarterly 2010.

[25] Stigson B. Beyond Copenhagen - the Green Race is on. e8 Symposium. 2010.

[26] Huhne C, Röttgen N, Borloo J-L. Europe needs to reduce emissions by $30 \%$. Financial Times 2010

[27] Harvey F. Business backs higher emission goals. Financial Times 2010.

[28] Agon J-P. Lay foundation for low-carbon growth. Financial Times 2010.

[29] Ernst \& Young. The business response to climate change. Paths chosen by top economies; 2009.

[30] Ernst \& Young. The business response to climate change. Choosing the right path; 2009.

[31] Neves AR, Leal V. Energy sustainability indicators for local energy planning: review of current practices and derivation of a new framework. Renewable and Sustainable Energy Reviews 2010;14:2723-35.

[32] European Commission. Covenant of Mayors; 2010. http://www.eumayors.eu/ September 22nd 2010.

[33] C40 Cities; 2010. http://www.c40cities.org/ September 22nd 2010.

[34] Commission of the European Communities. Winning the battle against global climate change. 2005.

[35] United Nations Framework Convention on Climate Change. Report of the Conference of the Parties on its fifteenth session held in Copenhagen from 7 to 19 December 2009. Part two: action taken by the Conference of the Parties at its fifteenth session. Decisions adopted by the Conference of the Parties; 2010.

[36] Commission of the European Communities. Limiting Global Climate Change to 2 degrees Celsius. The way ahead for 2020 and beyond. Communication from the Commission to the Council, the European Parliament, the European Economic and Social Committee and the Committee of the Regions; 2007.

[37] Commission of the European Communities. Action plan for energy efficiency: realising the potential; 2006.

[38] Commission of the European Communities. Renewable Energy Road Map. Renewable energies in the 21st century: building a more sustainable future. Communication from the Commission to the Council and the European Parliament; 2007. 
[39] European Parliament and the Council. Directive 2003/87/EC of the European Parliament and of the Council of 13 October 2003 establishing a scheme for greenhouse gas emission allowance trading within the Community and amending Council Directive 96/61/EC. Official Journal of the European Union; 2003.

[40] European Parliament and the Council. Directive 2009/29/EC of the European Parliament and of the Council of 23 April 2009 amending Directive 2003/87/EC so as to improve and extend the greenhouse gas emission allowance trading scheme of the Community. Official Journal of the European Union 2009.

[41] Guélaud C, Landrin S, Caramel L. Taxe carbone: ce sera 17 euros la tonne de $\mathrm{CO}_{2}$. Le Monde; 2009.

[42] Flemish Government. Besluit van de Vlaamse Regering van 16 mei 2007 houdende subsidiëring van bedrijventerreinen. Belgisch Staatsblad; 2007.

[43] Ricard P. Les Vingt-Sept lancent l'idée d'une taxe carbone au sein de l'Union pour lutter contre le changement climatique. Le Monde; 2009.

[44] National Climate Commission. Belgium's fifth national communication. Climate change. Under the United Nations framework convention on climate change; 2009.

[45] European Parliament and the Council. Decision No 406/2009/EC of the European Parliament and of the Council of 23 April 2009 on the effort of Member States to reduce their greenhouse gas emissions to meet the Community's greenhouse gas emission reduction commitments up to 2020. Official Journal of the European Union 2009.

[46] Gore A. Our choice. A plan to solve the climate crisis; 2009.

[47] Flemish Government. Ministerieel besluit van 1 oktober 2007 houdende de uitwerking van de $\mathrm{CO}_{2}$-neutraliteit op bedrijventerreinen. Belgisch Staatsblad; 2007.

[48] Flemish Government. Ministerieel besluit van 5 juni 2009 tot wijziging van artikelen $5,6,8,10$ en 11 van het ministerieel besluit van 1 oktober 2007 houdende de uitwerking van de $\mathrm{CO}_{2}$-neutraliteit op de bedrijventerreinen. Belgisch Staatsblad; 2009.

[49] Decraecke D. Energie Anders! NU. Flanders' Chamber of Commerce and Industry; Unpublished results.

[50] Lodewijks P, Brouwers J, Van Hooste H, Meynaerts E. Milieurapport Vlaanderen. Energie- en Klimaatscenario's voor de sectoren Energie en Industrie. Vlaamse Milieumaatschappij; 2009.

[51] The Carbon Trust. Product carbon footprinting: the new business opportunity. Experience from leading companies; 2008.

[52] Lysen EH.The Trias Energica: solar energy strategies for developing countries. Eurosun Conference. 1996.

[53] Flemish Government. Decreet van 22 december 2006 houdende eisen en handhavingsmaatregelen op vlak van de energieprestaties en het binnenklimaat van gebouwen en tot invoering van een energieprestatiecertificaat en tot wijziging van artikel 22 van het REG-decreet. Belgisch Staatsblad; 2007.

[54] Flemish Government. Besluit van de Vlaamse Regering van 11 maart 2005 tot vaststelling van de eisen op het vlak van de energieprestaties en het binnenklimaat van gebouwen. Belgisch Staatsblad; 2005.

[55] Intermunicipal Association Leiedal; 2010. http://www.evolisbusinesspark.be/ August 19th 2010.

[56] BECO Belgium. Deelplan $\mathrm{CO}_{2}$-neutraliteit site Duwijck. Lier; 2008.

[57] Veneco ${ }^{2}$. Deelplan $\mathrm{CO}_{2}$-neutraliteit; 2007.

[58] Innovista Eco-Industrial Park; 2010. http://www.eip.hinton.ca/ August 16th 2010.

[59] Taiga Nova Eco-Industrial Park; 2010. http://www.taiganova.com/ August 16 th 2010.

[60] VMM. Milieurapport Vlaanderen. Milieuverkenning 2030: Philippe D’Hondt. Vlaamse Milieumaatschappij; 2009.

[61] Roberts BH. The application of industrial ecology principles and planning guidelines for the development of eco-industrial parks: an Australian case study. Journal of Cleaner Production 2004;12:997-1010.

[62] Aro T. Preconditions and tools for cross-sectoral regional industrial GHG and energy efficiency policy - a Finnish standpoint. Energy Policy 2009;37:2722-33.

[63] Erkman S. Industrial ecology: an historical view. Journal of Cleaner Production 1997;5:1-10.

[64] Chertow MR. Industrial symbiosis: literature and taxonomy. Annual Review of Energy and the Environment 2000;25:313-37.

[65] Lowe EA, Moran S, Holmes D. Fieldbook for the Development of Eco-Industrial Parks; 1995.

[66] Lowe EA. Creating by-product resource exchanges: strategies for eco-industrial parks. Journal of Cleaner Production 1997;5:5765.

[67] Liwarska-Bizukojc E, Bizukojc M, Marcinkowski A, Doniec A. The conceptual model of an eco-industrial park based upon ecological relationships. Journal of Cleaner Production 2009;17:732-41.

[68] Elkington J. Cannibals with forks: the triple bottom line of the 21ste century business. Capstone: Oxford; 1997.

[69] Van Eetvelde G, Deridder K, Segers S, Maes T, Crivits M. Sustainability scanning of eco-industrial parks. 11th European Roundtable on Sustainable Consumption and Production (ERSCP), Basel; 2007.

[70] Côté RP, Cohen-Rosenthal E. Designing eco-industrial parks: a synthesis of some experiences. Journal of Cleaner Production 1998;6: $181-8$.

[71] Coté R, Hall J. Industrial parks as ecosystems. Journal of Cleaner Production $1995 ; 3: 41-6$.
[72] Elabras Veiga LB, Magrini A. Eco-industrial park development in Rio de Janeiro Brazil: a tool for sustainable development. Journal of Cleaner Production 2009; 17:653-61.

[73] Coté RP, Smolenaars T. Supporting pillars for industrial ecosystems. Journal of Cleaner Production 1997;5:67-74.

[74] Lambert AJD, Boons FA. Eco-industrial parks: stimulating sustainable development in mixed industrial parks. Technovation 2002;22:471-84.

[75] Heeres RR, Vermeulen WJV, de Walle FB. Eco-industrial park initiatives in the USA and the Netherlands: first lessons. Journal of Cleaner Production 2004;12:985-95.

[76] Van Zwam B, Brepoels S, Breugelmans M, Claeys S, Drijvers D, et al. In: Van Dyck B, editor. Reststromen in de Gentse Kanaalzone: onderzoek naar mogelijkheden voor uitwisseling en valorisatie. Gents Milieufront; 2008. p. 65.

[77] Laybourn P, Morrissey M. National Industrial Symbiosis Programme. The pathway to a low carbon sunstainable economy; 2009.

[78] Sterr T, Ott T. The industrial region as a promising unit for eco-industria development - reflections, practical experience and establishment of innovative instruments to support industrial ecology. Journal of Cleaner Production 2004;12:947-65.

[79] Tudor T, Adam E, Bates M. Drivers and limitations for the successful development and functioning of EIPs (eco-industrial parks): a literature review. Ecological Economics 2007;61:199-207.

[80] Maes T, Van Eetvelde G, Van Zwam B, Ploos van Amstel W. Parkmanagement: living apart-together. Logistieke samenwerking als remedie voor de logistieke sector? Vervoerslogistieke werkdagen 2008. Deurne Nederland; 2008.

[81] Frosch RA, Gallopoulos NE. Strategies for manufacturing. Scientific American 1989;261:144-52.

[82] Jelinski LW, Graedel TE, Laudise RA, Mccall DW, Patel CKN. Industrial ecology - concepts and approaches. Proceedings of the National Academy of Sciences of the United States of America 1992;89:793-7.

[83] Lifset R, Graedel TE. Industrial ecology: goals and definitions. In: Ayres RU, Ayres LW, editors. A handbook of industrial ecology. Edward Elgar Publishing Limited; 2002. p. 652.

[84] Ayres RU. On the life cycle metaphor: where ecology and economics diverge. Ecological Economics 2004;48:425-38.

[85] Fichtner W, Frank M, Rentz O. Inter-firm energy supply concepts: an option for cleaner energy production. Journal of Cleaner Production 2004;12:891-9.

[86] Beyene A. Combined heat and power as a feature of energypark. Journal of Energy Engineering-ASCE 2005;131:173-88.

[87] Jiayi H, Chuanwen J, Rong X. A review on distributed energy resources and MicroGrid. Renewable and Sustainable Energy Reviews 2008;12:2472-83.

[88] Battaglini A, Lilliestam J, Haas A, Patt A. Development of SuperSmart Grids for a more efficient utilisation of electricity from renewable sources. Journal of Cleaner Production 2009;17:911-8.

[89] Bayod-Rújula AA. Future development of the electricity systems with distributed generation. Energy 2009;34:377-83.

[90] Farhangi H. The path of the Smart Grid. IEEE Power \& Energy Magazine 2010

[91] Van Eetvelde G, Delange E, De Zutter B, Matthyssen D, Gevaert L, Schram A, et al. Groeiboeken Duurzame BedrijvenTerreinen juridisch, economisch, ruimtelijk, technisch bekeken. Vanden Broele Grafische Groep 2005.

[92] Van Eetvelde G, Van Zwam B, Maes T, Vollaard P, De Vries I, Tavernier P, et al. Praktijkboek duurzaam bedrijventerreinmanagement. Vanden Broele Grafische Groep 2008.

[93] The Kalundborg Centre for Industrial Symbiosis; 2010 http://www.symbiosis.dk/ September 29th 2010.

[94] Desrochers P. Industrial symbiosis: the case for market coordination. Journal of Cleaner Production 2004;12:1099-110.

[95] Waldmann A, Keuc A. Making energy services SME attractive. Efficient implementation of energy services in small and medium sized enterprises - EFFI. Ljubljana 2009.

[96] Cooremans C. Strategic fit of energy efficiency. Strategic and cultural dimensions of investment decisions. In: Behaviour, Energy \& Climate Change Conference, Sacramento, CA; 2008.

[97] Goeijenbier PGHM, Vlaar LNC. Achtergronden energieclustering glastuinbouw. V. E. K. Adviesgroep; 2005.

[98] de Man G. Samenwerkingsverband voor lokale productie, case study. Brussels: Energy Forum; 2009.

[99] Ovink P. Nuon Industrieparkmanagement; 2009.

[100] Commission for Architecture and the Built Environment; 2010 http://www.cabe.org.uk/ August 19th 2010.

[101] Elephant \& Castle.; 2010. http://www.elephantandcastle.org.uk/ August 19th 2010.

[102] Block C, Van Praet B, Windels $T$, Vandecasteele $C$, To a $\mathrm{CO}_{2}$ neutral industry park: case study (Naar een $\mathrm{CO}_{2}$-neutraal industrieel ecopark). Dissertation Leuven University; 2009.

[103] Saint Trofee. Cold storage of wind energy; 2010. http://www.tnorefrigeration.com/ August 19th 2010.

[104] Vlaamse Energieagentschap; 2010. http://www.energiesparen.be/ September 29th 2010.

[105] WES Onderzoek en Advies. Duurzame kwaliteit voor bedrijventerreinen. Draaiboek; 2006. p. 99.

[106] Van Reeth b. Het langdurige dat toeval mogelijk maakt en verbeelding. In: De Kooning M, editor. Bob van Reeth. Teksten van en over. Gent: Ghent University; 1983.

[107] Koolhaas R. Urbanism after Innocense: Four Projects: The reinvention of geometry. Assemblage 1992:18. 
[108] Rossi A. De architectuur van de stad. Sun 2002.

[109] Van Reeth b. Tomorrow never happens. In: De Kooning M, editor. Bob van Reeth Teksten van en over. Gent: Ghent University; 1983.

[110] Grontmij Advies \& Techniek, RuimBuiten, Eye Locus, Provincie Zuid-Holland. Hoe werkt de toekomst; 2003. p. 62.

[111] Arcadis, Arcadis Ecolas, Ghent University, Power-Link, DLA Piper. Ontwerp van een duurzaam bedrijventerrein; 2008.
[112] BECO Belgium, Stibbe, BOFIDI, Fortech Studie, Ghent University AMRP Environmental and Spatial Management. Handleiding $\mathrm{CO}_{2}$-neutraliteit; 2009.

[113] Chae SH, Kim SH, Yoon S-G, Park S. Optimization of a waste heat utilization network in an eco-industrial park. Applied Energy 2010;87: 1978-88.

[114] BlueNext; 2010. http://www.bluenext.eu/ August 26th 2010. 